\title{
Las fiestas de canonización
}

\section{de san Luis Bertrán en Roma (I67I). Precisiones documentales acerca de los artistas participantes}

\author{
Marià Carbonell Buades \\ Universitat Autònoma de Barcelona \\ mariano.carbonell@uab.cat
}

Recepción: 07/05/2018, Aceptación: 13/08/2018, Publicación: 04/12/2018

\section{RESUMEN}

La fiesta barroca, en general, y la relativa a las canonizaciones del siglo XVII, en particular, han generado abundante bibliografía, que solo eventualmente aprovecha fuentes documentales primarias. Entre los fondos de archivo menos consultados hay que contar los protocolos notariales. Ahora se dan a conocer los recibos firmados por los artistas que participaron en las fiestas romanas de canonización de san Luis Bertrán (I67I) a favor del P. Pedro Lorente O. P., procurador de la causa pía, conservados en el Archivio Storico Capitolino de Roma.

Palabras clave:

Fiesta de canonización; fiesta barroca; san Luis Bertrán; dominicos; Lazzaro Baldi; Giovan Battista Gaulli; Giovanni Carbone; Francesco Ludovisi; Alexio Colino; Giuseppe Paglia

\section{ABSTRACT}

The canonization ceremonies of Saint Louis Bertrand in Rome (I67I). Documentary evidences on participating artists

The Baroque Festival and, in particular, the canonization ceremonies in the $17^{\text {th }}$ century have generated a large amount of bibliography. However, this bibliography rarely uses primary documentary sources. Notarial registers are amongst the least consulted archives. This paper discloses the payment receipts signed by artists participating in the Roman celebrations for the canonization of Saint Louis Bertrand (I67I) in favour of Fr. Pedro Lorente O. P as a procurator of the pious cause. All these receipts are preserved in the Archivio Storico Capitolino in Rome.

Keywords:

Canonization Ceremonies; Baroque Festival; Saint Louis Bertrand; Dominican Order; Lazzaro Baldi; Giovan Battista Gaulli; Giovanni Carbone; Francesco Ludovisi; Alexio Colino; Giuseppe Paglia 
$\mathrm{E}$ 1 fraile dominico Luis Bertrán (Valencia, I 526-I58I) fue beatificado el i9 de julio de 1608 por Paulo $\mathrm{V}$ y canonizado el I 2 de abril de i67i por Clemente X. Como era habitual, ambas solemnidades fomentaron la publicación de escritos hagiográficos, la mayoría de los cuales hacen referencia al ceremonial desplegado en la basílica vaticana y a otros festejos públicos que tuvieron lugar en la misma ciudad o en otros lugares relacionados con el flamante santo. Por ejemplo, a raíz de la beatificación, se imprimieron dos relaciones diferentes de las fiestas celebradas en Valencia, escritas por el dramaturgo Gaspar Aguilar y el dominico fray Vicente Gómez. Son publicaciones voluminosas, que dedican más o menos atención a la descripción del aparato decorativo, aunque omiten detalles significativos, como el nombre de los artistas participantes ${ }^{1}$. A veces, una simple narración biográfica también nos informa de las ceremonias festivas y, accidentalmente, de las obras de arte que generaban. Es el caso de fray José Favores O. P., procurador de la ciudad de Valencia en la curia romana para la causa de canonización de su correligionario ${ }^{2}$. El panegirista alude a las fiestas celebradas en diversas ciudades italianas a lo largo del año r67i (Roma, Milán, Pavía, Castrí $[s i c]^{3}$, Nápoles, etc.) y anuncia otras previstas en el viejo y el nuevo continente. Cosa más rara, recuerda, aunque dejándolos en el anonimato, los veintidós cuadros figurando milagros del santo que tuvo a bien pagar el marqués de Centelles, es decir, Joaquín Carròs de Centelles y de Calatayud, marqués de Quirra y de Nules, destinados a un octavario que él mismo había subvencionado ${ }^{4}$. A primera vista, se podría pensar que iban destinados a las celebraciones valencianas del mes de septiembre de $167 \mathrm{I}^{5}$, pero es más probable que el autor se refiera a
Nápoles, ya que el marqués también colaboró en las fiestas de canonización de san Cayetano que tuvieron lugar en la iglesia de San Paolo Maggiore ${ }^{6}$. Ocasionalmente, la fiesta podía ser promovida por un gremio o una cofradía, como en el caso del auto glorioso que auspició el colegio de notarios de la ciudad de Valencia, incluida la fastuosa decoración efímera de la iglesia de los dominicos diseñada por el famoso escenógrafo Josep Caudî. Esta celebración compensaba la oficial, que se limitó, por decisión de la reina, a una procesión entre el convento dominico y la catedral, una misa solemne, un octavario y las habituales luminarias. En aquella ocasión, además del cuerpo incorrupto del santo, se sacó en procesión una escultura relicario fabricada en plata por Josep Seguers (figura I) ${ }^{9}$. Los restos del fraile se conservaban en una urna de plata seiscentista, después substituida por la que pagó Mariana de Bracamonte, condesa de Alcudia, y que fabricó Gaspar Lleó - acabada, sin embargo, por Francesc Pinyol- entre 1739 y 1744 (figura 2) ${ }^{10}$.

En definitiva, para la historia del arte toda esta literatura (relaciones de fiestas, biografías, etc.) constituye una fuente primaria imprescindible, pero también insuficiente. Otros fondos documentales que se han utilizado esporádicamente son los registros contables del Banco di Santo Spirito y del Monte di Pietà de Roma y los archivos romanos de las congregaciones religiosas implicadas, en particular para san Filippo Benizi ${ }^{11}$ y san Francisco de Bor$\mathrm{ja}^{12}$. En cambio, no han tenido un tratamiento tan detallado las actividades relacionadas con los otros tres canonizados en la misma ceremonia, empezando por nuestro san Luis Bertrán $^{13}$. Una tipología documental poco explorada son los protocolos notariales, de los que ahora presento un ejemplo; en concreto, los 


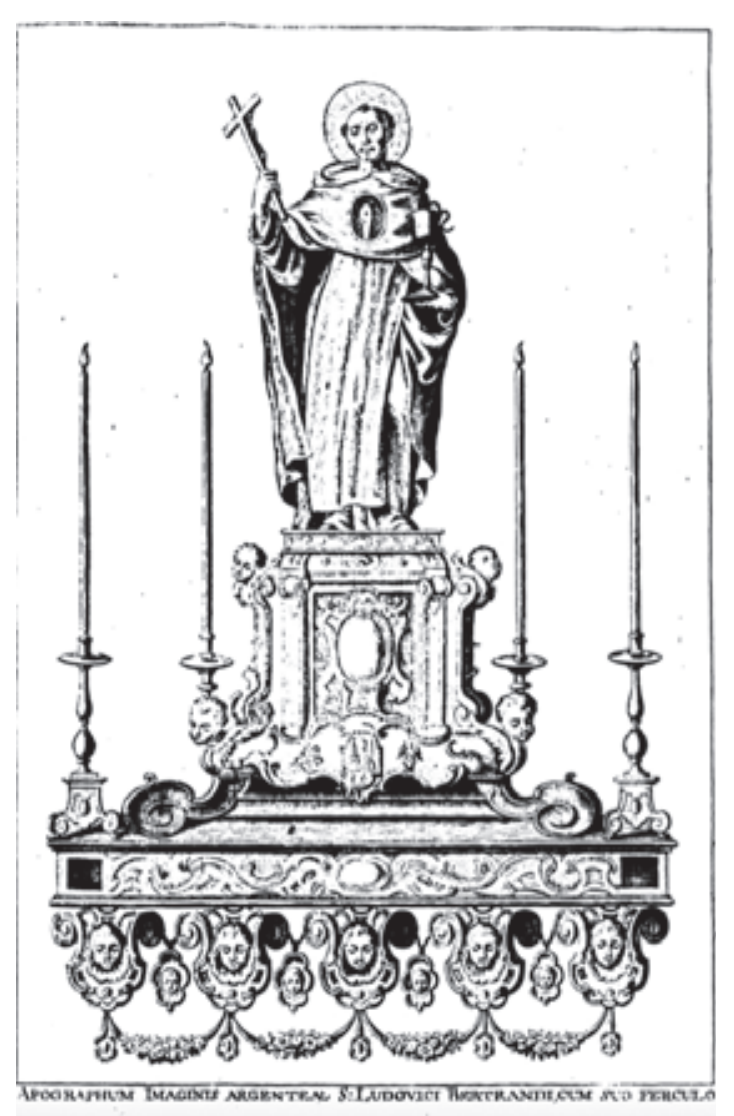

Figura 1.

Josep SEGUERS, 1671, estatua relicario de plata de san Luis Bertrán, desaparecida de la catedral de Valencia (Acta sanctorum octubris, 1786).

recibos firmados por los diferentes artistas que colaboraron en las fiestas romanas de canonización del dominico, tanto en la basílica vaticana como en la iglesia de Santa Maria sopra Minerva (apéndice documental I ${ }^{14}$. La propia tipología documental justifica que algunos de estos recibos sean menos detallados de lo que sería deseable y, por otra parte, no se puede descartar la posibilidad de que se hicieran otros desembolsos con la misma finalidad. En todo caso, los pagos fueron efectuados por el procurador del convento valenciano en la causa pía, el P. fray Pedro Lorente, parte en metálico y parte a través del citado ban$\mathrm{co}^{15}$. Había sido nombrado procurador el i 9 de mayo de r668 en substitución del P. fray Vicente Saborit, muy activo en los años anteriores y biógrafo del santo ${ }^{16}$.

El ritual genuinamente canónico tenía lugar en la basílica de San Pedro ${ }^{17}$. Por fortuna, disponemos de abundante información relativa a la ceremonia del año i67I, no solo porque en la práctica el género literario dedicado a la descripción de fiestas barrocas se había institucionalizado (llamada casi siempre relación) ${ }^{18}$, sino también porque los llamados cinque santi clementini habían alcanzado verdadera transcendencia universal, empezando por Francisco

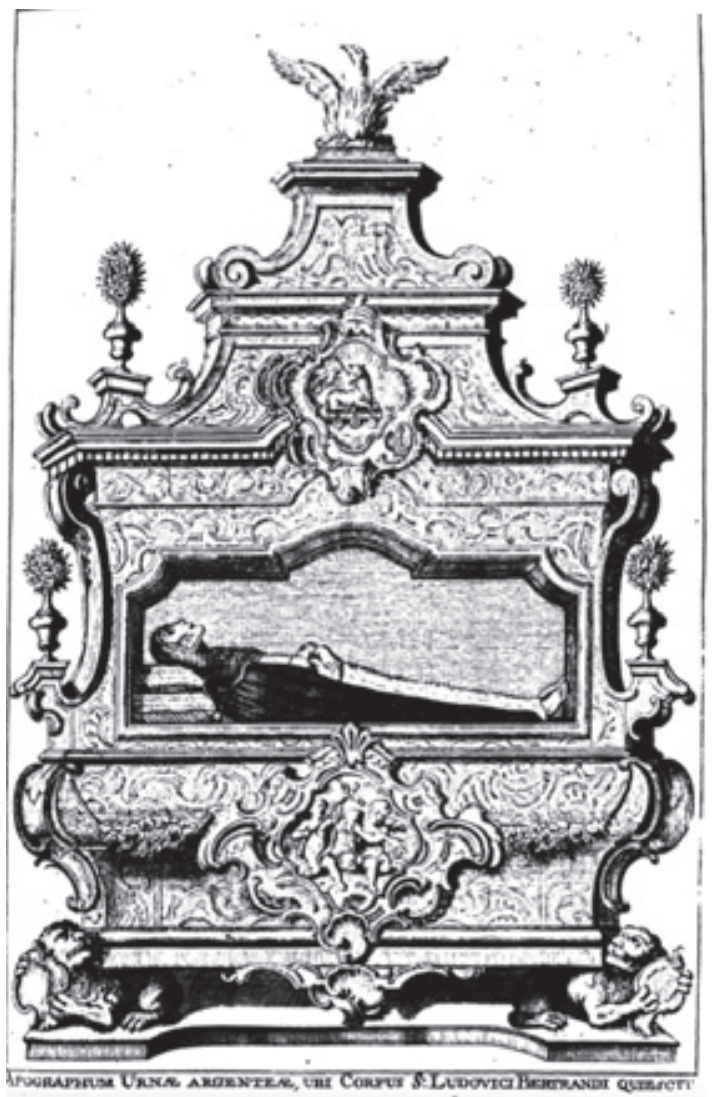

Figura 2.

Gaspar Lleó, 1739-1744, urna de plata de san Luis Bertrán para el convento dominico de Valencia, desaparecida (Acta sanctorum octubris, 1786).

de Borja y Cayetano Thiene ${ }^{19}$. Un tercer beneficiado, el florentino Filippo Benizi, que había sido general de los Siervos de María o servitas en el siglo XIII y beatificado en I s 6 , era el primer miembro de su orden en ser canonizado. Por último, los otros dos eran dominicos, Rosa de Lima y Luis Bertrán, vinculados, la una por nacimiento y el otro por vocación misionera, a las colonias hispanoamericanas. La monja peruana, de origen criollo y la primera persona nacida en América que subía a los altares, había sido beatificada en 1668 por Clemente IX en la basílica vaticana y en otros templos romanos, como se describe detalladamente en las relaciones correspondientes ${ }^{20}$. En cambio, su colega de religión tuvo que penar un proceso más dilatado, interrumpido a causa de los decretos de Urbano VIII en materia de canonizaciones. Aunque se daba por concluida a finales de I62 I, la causa fue interrumpida a la muerte de Gregorio XV y no se pudo reanudar hasta $\mathrm{I} 660$. Que cinco años antes ya se hubiera iniciado la recogida de limosnas, sobre todo en territorio americano, es un indicio del interés infatigable que Felipe IV y la orden de dominicos demostraron por la causa ${ }^{21}$. El hecho es que, a partir de i660, los procesos de ambos dominicos fueron de la 


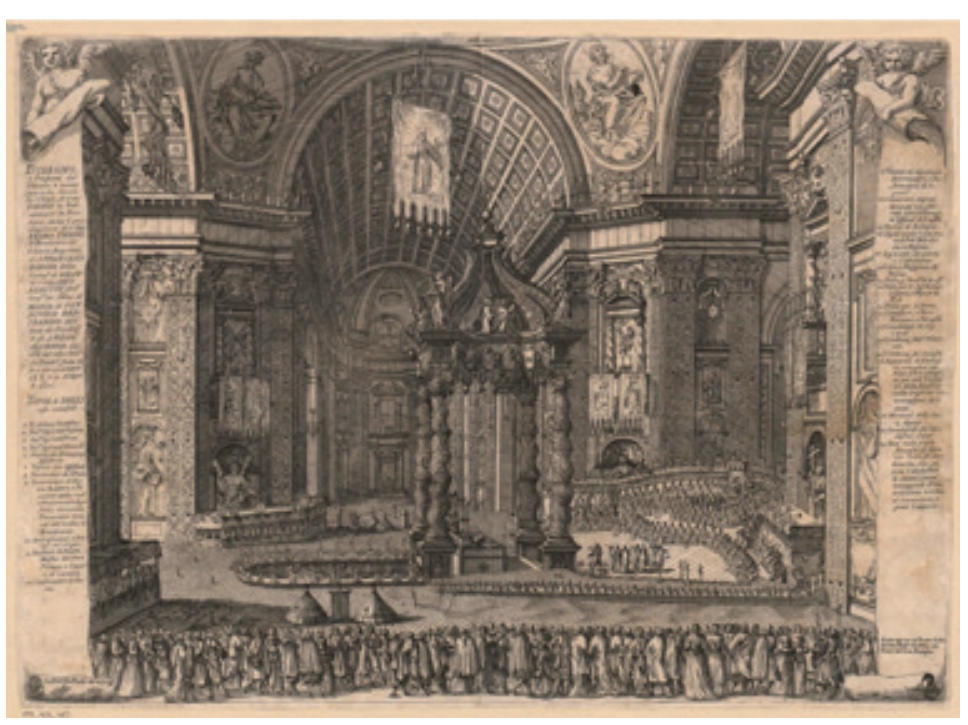

Figura 3.

Giovan Battista Falda (dibujo y grabado), 1671, Disegno e Prospetto del Theatro, e nuovo Apparatto dentro la Chiesa di San Pietro in Vaticano per la fontione della Canonizatione [...] fatta da N. S. PP. Clemente X li 12 di Aprile 1671... Kunstbibliothek, Staatliche Museen zu Berlin.

mano y se aceleraron, sobre todo gracias a los buenos oficios de los procuradores respectivos: por el fraile valenciano, el citado P. Vicente Saborit ${ }^{22}$; por la monja limeña, el P. fray Antonio González de Acuña, su biógrafo y futuro obispo de Caracas ${ }^{23}$. En I662 se recibían en Valencia las litterae remissoriales con el objetivo de verificar de nuevo la vida y las virtudes heroicas del fraile. Finalmente, el proceso culminó el 4 de octubre de 1667 con el decreto de aprobación de los milagros, dieciocho que le habían sido reconocidos tiempo atrás y cuatro de nuevos. La canonización coincidió con la elección en I670 como general de la orden de fray Juan Tomás de Rocabertí, hijo de los condes de Peralada, exprovincial de la Corona de Aragón y, elocuentemente, procurador general de la causa pía de Luis Bertrán durante la magistratura de su antecesor, Giovanni Battista de Marinis. El P. Rocabertí se sentía heredero de la reforma espiritual que propugnaba el valenciano y lo demuestra en su Theologia Mystica (Barcelona, I699), que le dedicó y que ilustró con un grabado donde se le ve evangelizando a aborígenes americanos $^{24}$. La canonización de I67I era una demostración explícita del poder de la orden de predicadores, la confirmación de que era un seminarium sanctorum, en expresión del cardenal Baronio $^{25}$. Por otra parte, la monarquía hispana se permitía subrayar la validez de su política evangelizadora en tierras americanas o, mejor dicho, en su formato más global, ya que Luis Bertrán fue nombrado por la Congregación de Ritos patrón de la Nueva Granada (I690), y Rosa de Lima, patrona de América, Filipinas e Indias Orientales ( 1670$)^{26}$.
La Relatione anónima de la ceremonia celebrada el I 2 de abril de I67 I dedica un capítulo independiente al apparato desplegado en la basílica vaticana, aunque incomprensiblemente solo cita el nombre de un pintor, Giovanni Carbone (apéndice documental 2) ${ }^{27}$. Por fortuna, como se ha avanzado, otras fuentes documentales han permitido algunas publicaciones que reconstruyen con notable precisión los aspectos artísticos de la canonización, al menos para san Filippo Benizi y san Francisco de Borja. Por otra parte, gracias a un grabado de G. B. Falda que reproduce el interior de la basílica vaticana durante la ceremonia (figura 3), disponemos de información gráfica del acontecimiento. En realidad, se trata de una plancha reaprovechada, diseñada dos años antes para la canonización de los santos Pedro de Alcántara y María Magdalena de Pazzi, cambiando algunos detalles y las leyendas laterales. Como ha explicado Vittorio Casale, el protocolo de las canonizaciones conllevaba dos ceremonias complementarias, intrínsecamente ligadas aunque diferentes en el tiempo y en el significado. La primera tenía lugar en la basílica pietrina y consistía en el ritual estricto de canonización, con la correspondiente inclusión del nombre del bienaventurado en el catálogo oficial de santos (canon, de aquí el nombre) y la fijación de su fiesta en el calendario litúrgico. La segunda celebración se desarrollaba en la iglesia correspondiente a cada santo o a cada orden religiosa, depende del caso - Santa Maria sopra Minerva para los dominicos-, donde durante el octavario se desplegaba un aparato ornamental fastuoso y se llevaba en procesión el estandarte con la imagen del flamante santo. Los artistas implicados eran numerosos, y más en el caso de una canonización múltiple como la de i67r. Para la basílica vaticana se necesitaban retratos individuales de los cinco santos, los respectivos estandartes y grandes medallones que colgaban de los intercolumnios con los correspondientes milagros. Los estandartes podían multiplicarse, como los tres que encargaron los servitas, y había al menos uno de colectivo que se ha atribuido a Ciro Ferri (figura 4). Todo esto sin contar con los grabados, individuales y de grupo. Un ejemplo de este último tipo es el que el lorenés François Spierre dedicó al cardenal Paluzzo Altieri, nipote de Clemente X (figura 5). De hecho, el papa se mostró personalmente interesado en la conmemoración de los nuevos santos hasta el punto de hacer remodelar la capilla familiar de la iglesia de la Minerva, para lo cual destinó solo 6.000 escudos ("per renderla più maestosa che rica»). Nombró supervisor de las obras al cardenal Camillo Massimo, que impuso un gusto anticuario y sobrio, inspirado en el vecino Panteón ${ }^{28}$. No 


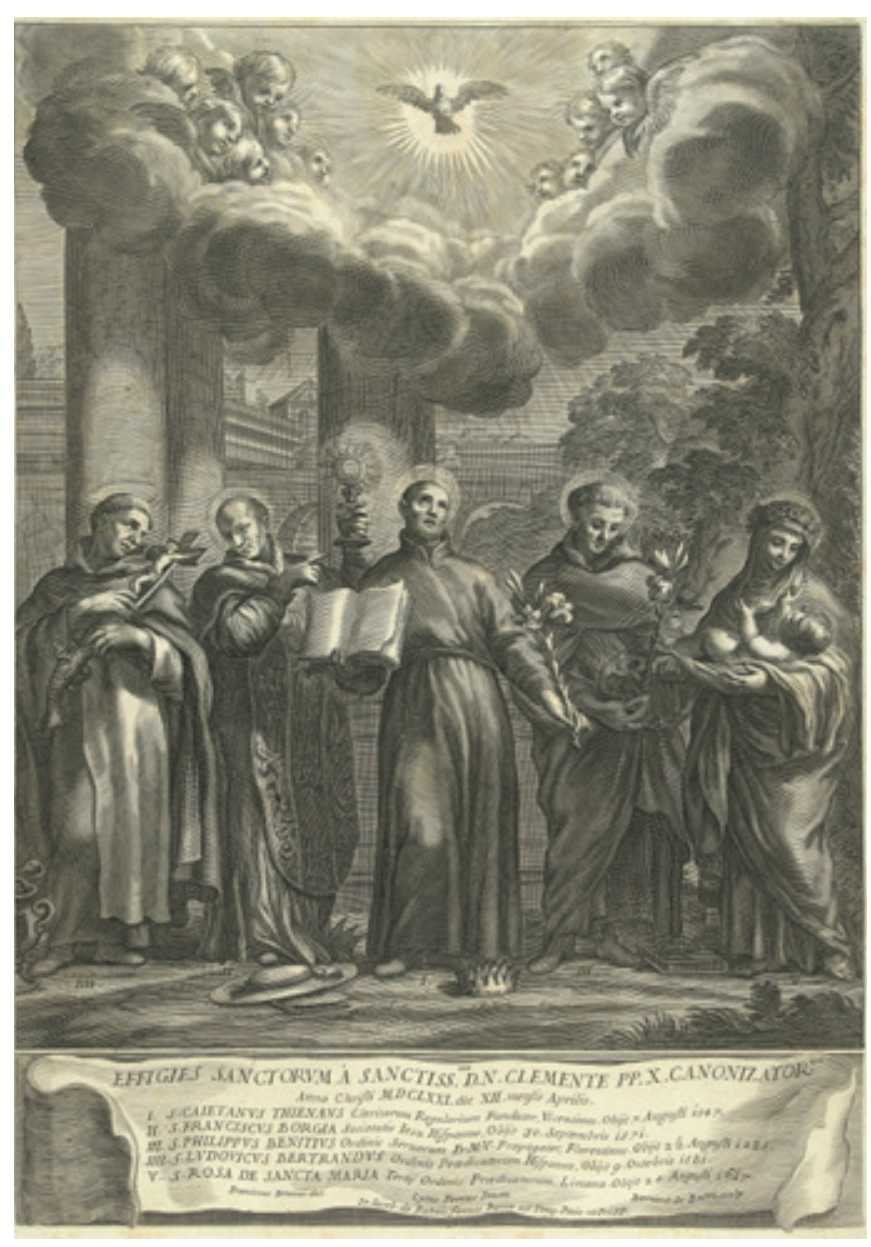

Figura 4.

Ciro FerRi (diseño), Francesco Bruno (dibujo), B. de BAIlliu (grabado), 1671, Los cinco santos canonizados por Clemente X. Rijksmuseum. Amsterdam.

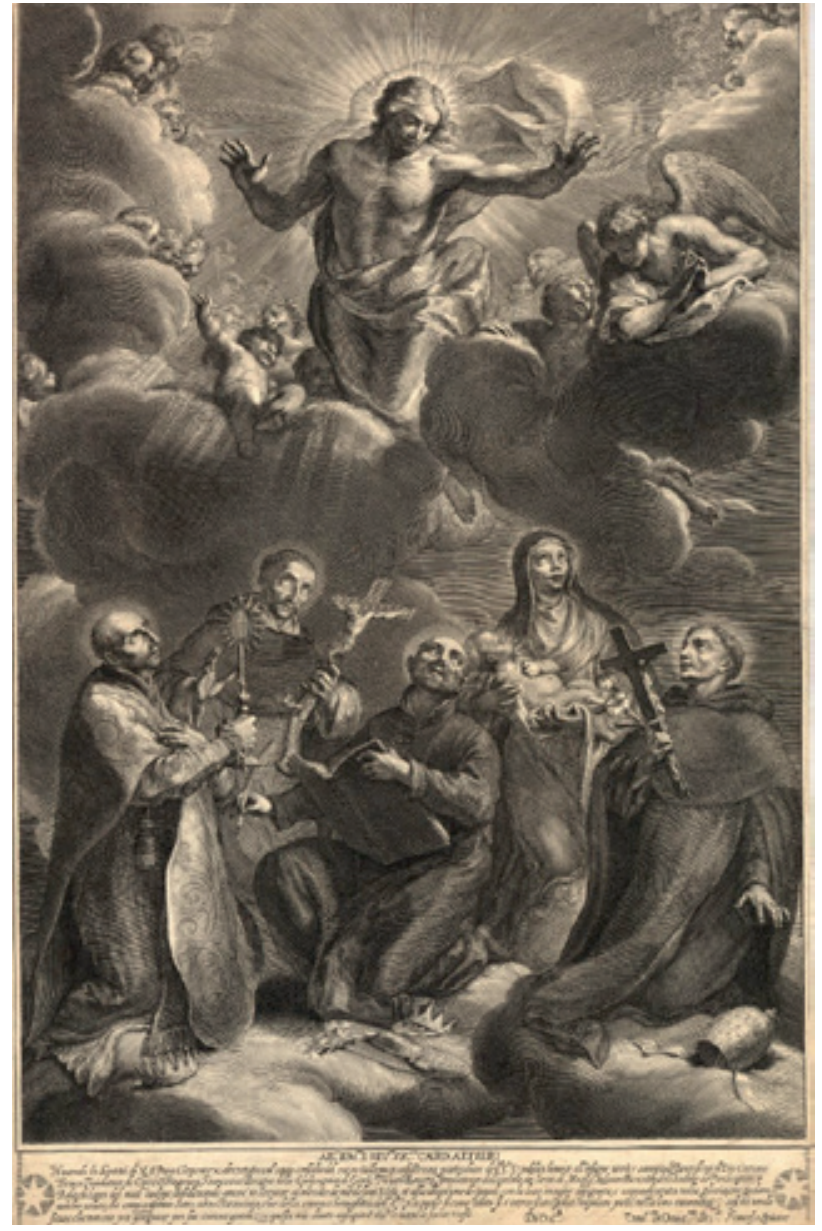

Figura 5.

François SPIERRE (dibujo y grabado), 1671, Cristo con los cinco santos canonizados por Clemente X. British Museum. Londres. se conoce el nombre del arquitecto, pero sí el de otros artistas participantes: el escultor Cosimo Fancelli; Carlo Maratti, autor de la pala d'altare, con San Pedro que presenta a la Virgen los cinco santos canonizados por Clemente $X$, y Giovan Battista Gaulli, autor del fresco de la Trinidad que decora la luneta. La pintura del retablo fue rápidamente reproducida en un aguafuerte por Pietro Aquila (figura 6).

A raíz de la canonización, la iglesia minervitana experimentó más variaciones, ya que otras dos capillas cambiaron de advocación: la de la Trinidad se convirtió en la de santa Rosa de Lima y la de santo Domingo en la de san Luis Bertrán. A pesar de que ambas gozaban de la protección de familias aristocráticas -Capizucchi y Caffarelli, respectivamente-, fueron reformadas por voluntad de los dominicos, en buena parte gracias a las limosnas recogidas en América, un fondo que era administrado por el citado González de Acuña. De la escasa documentación exhumada se ha deducido que la planificación o al menos la dirección de las obras fue responsabilidad del también domini- co fray Giuseppe Paglia (I616-1683), un lego palermitano que residía en el mismo convento ${ }^{29}$. En realidad, el alcance de las intervenciones es muy diferente, porque la capilla de santa Rosa fue remodelada por completo (figura 7), mientras que la de san Luis únicamente experimentó modificaciones puntuales, incluida la apertura de las dos ventanas laterales. Los escasos pagos documentados a Paglia, siempre por parte de González de Acuña, se limitan a los años r 670 y i67 I y son muy genéricos. Solo en una ocasión se justifica que son "per lavori che si fanno alla cappella del [la] B. Rosa». En cambio, nunca aluden a la capilla del valenciano, de lo cual se puede inferir que la reforma fue muy limitada o, quizá, que el arquitecto dominico no intervino en ella. No era la primera vez que González de Acuña confiaba en Paglia. A finales de I669, Clemente IX promovió la renovación de la capilla de santo Domingo situada en la clausura del otro convento dominico de Roma, Santa Sabina. Es un reducido espacio de planta rectangular y techo envigado, precedido por una antecámara alargada cubierta con bóveda de cañón 


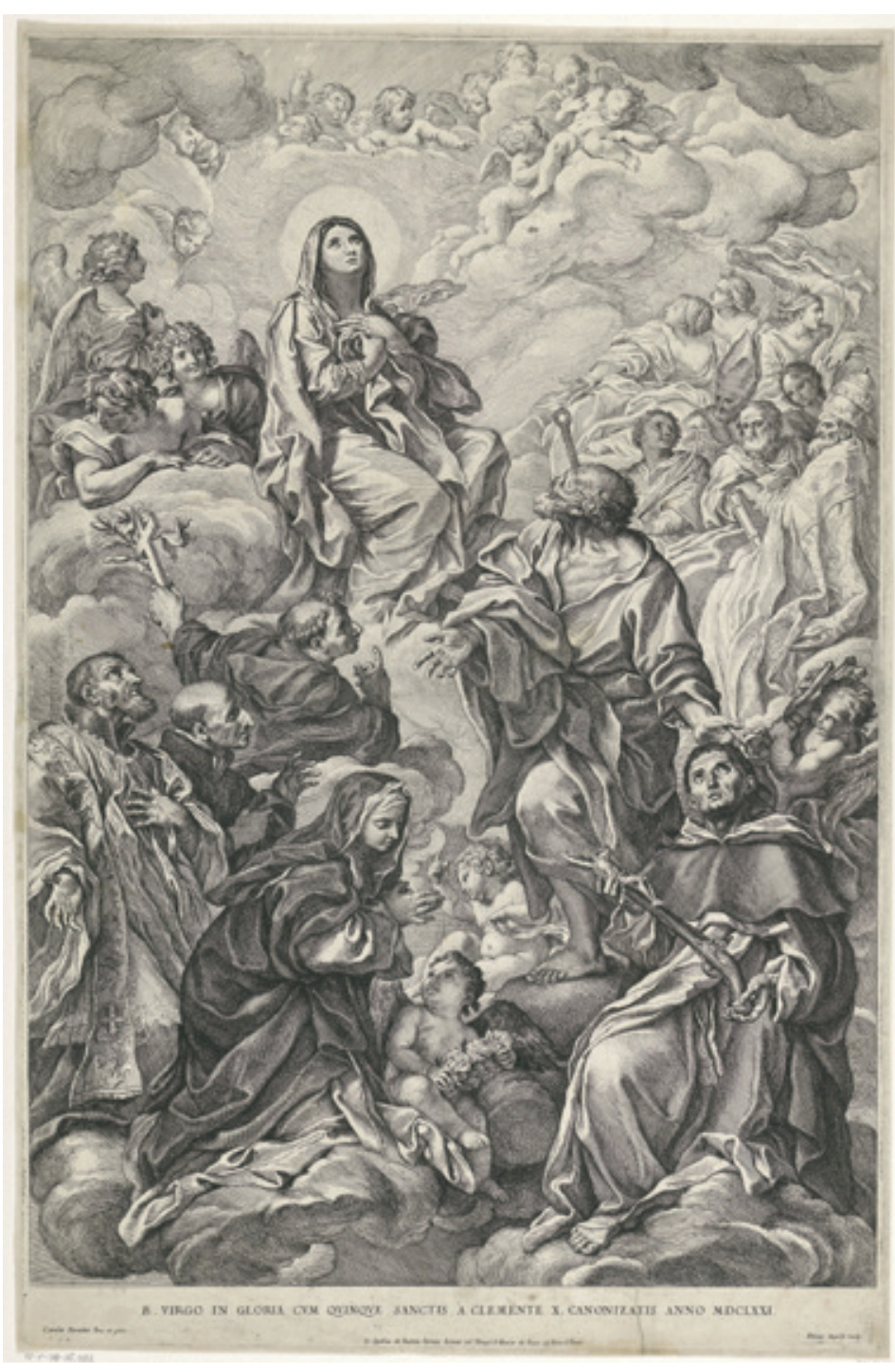

Figura 6.

Carlo MaratTi (diseño), Pietro Aquila (grabado), 1671, San Pedro presenta a la Virgen los cinco santos canonizados por Clemente X. Rijksmuseum. Amsterdam.

decorada con casetones y un fresco de Ludovico Gimignani. El lenguaje arquitectónico de la antecámara ha permitido atribuir el diseño a Bernini ${ }^{30}$ y, más recientemente, a partir de dos dibujos, se ha asignado la dirección de las obras a Mattia de Rossi ${ }^{31}$. Sin embargo, la aparición de nuevos documentos permite quizás introducir un matiz en este debate. En efecto, en marzo de I670, una serie de pagos por final de obra permiten saber que el director de una intervención indeterminada en el convento era el citado Paglia, que actuaba bajo la supervisión de A. González de Acuña, en memoria o por orden del difunto P. General de Marinis, de quien el limeño había sido secretario y persona de confianza. Es cierto que los documentos no son demasiado explícitos y solo en una ocasión mencionan la «camera sanctis Patris Dominici in conventu Sanctæ Sabine»; lo hacen, además, por labores textiles del bandararo florentino G. B. Bursaglia - a quien se volverá a citar"palliotto, cuscini, tendine di taffetano, cordini et aliorum ornamentum». El resto de recibos se refieren a trabajos propios de arquitectura a favor del scarpellino Alessandro Sarti, oriundo de la diócesis de Sarzana, del falegname Pietro Giglio, de Cortona (en su caso, el total alcanza los 490 escudos), del vetraro romano Jacopo Taffarelli y del stagnaro novarés G. B. Mora ${ }^{32}$. Nada demuestra que la obra se pueda identificar con la capilla dedicada al fundador, pero de antemano tampoco se puede descartar. Sea como fuere, la documentación demuestra la buena relación existente entre los dos frailes dominicos y justifica la elección de Paglia para reformar la capilla de santa Rosa de Lima. En este caso se trataba de una empresa personal, como queda explícito en la cesión que, en octubre del año I67I, el ya obispo de Caracas formalizaba a favor del generoso Lorenzo Onofre Colonna, príncipe de Paliano $^{33}$ :

Dijo [González de Acuña] que por quanto tiene fundado y fabricado ex fundamentis con todos sus adereços, ornamentos, requisitos y demás cosas necessarias a su costa una capilla so la invocación de Santa Rosa de Santa María Limana de dicho orden de Santo Domingo, su paesana y Patrona de las Indias, en la venerable Yglesia Conventual de Santa María llamada sobre la Minerva de dicho orden desta Alma Ciudad de Roma, a mano derecha de cómo se entra por el portón de dicha Yglesia que está en la plaçuela, junta y apegada a la capilla de San Luis Bertrán, assimismo de dicho orden, según sus demás confines, sitio y mejores límites, que los quiere haver aquí por expressados y especialmente calendados como si lo estuvieran, y en cuya fábrica de dicha capilla ha gastado más de diez mil escudos desta moneda de Roma, y pagado el suelo de ella al convento de Santo Domingo sobre dicha Minerva, y por quanto assimismo se ha ayudado para dicha fábrica y paga de dicho suelo de la protección, amparo y de muchas limosnas que ha sido servido darle, concederle y haçerle el Exmo. Señor Don Lorenço Onofre Colonna Gioeni, Príncipe Romano, Duque y Príncipe de Paliano etc. y Gran Condestable del Reyno de Nápoles, de tal suerte que con dichas limosnas y assistencias y con el suyo proprio debajo dicha protección está enteramente y perfectamente fabricada, acavada y ornada de todos ornamentos $y$ aparatos necessarios la sobredicha capilla de Santa Rosa, su paesana, y queriendo que Su Exca. tenga algún fruto y recompensa de sus limosnas, ayuda, amparo, protección y assis- 


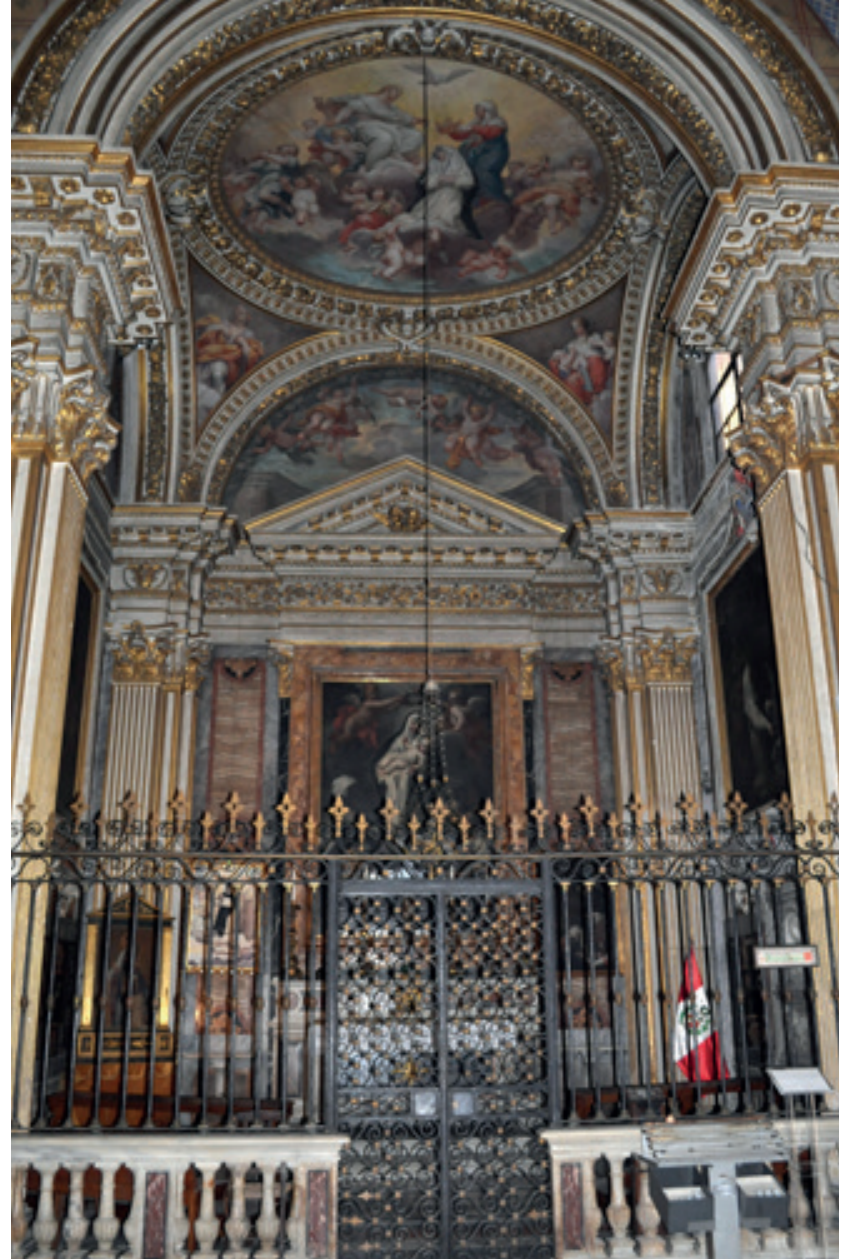

Figura 7.

Roma, Santa Maria sopra Minerva, capilla de santa Rosa de Lima, 1671. Foto del autor.

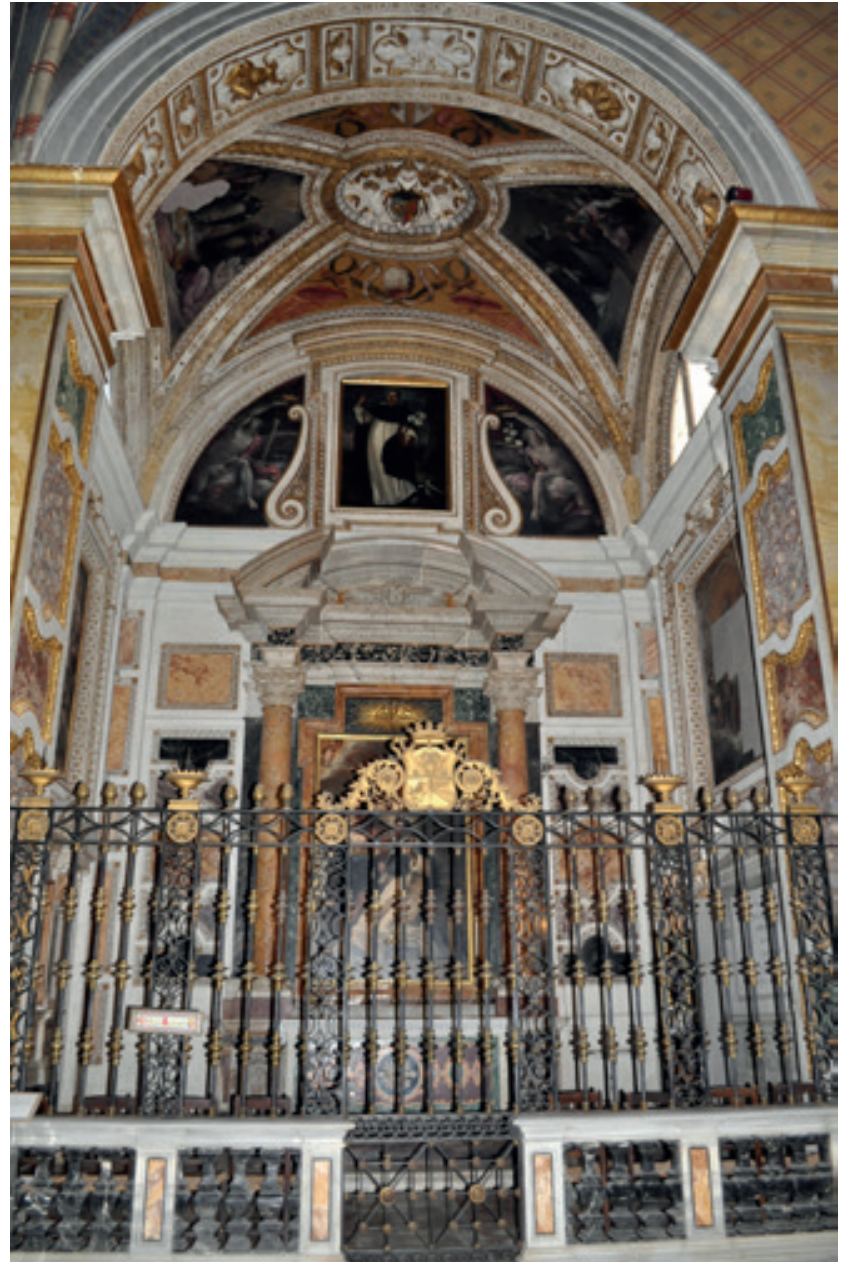

Figura 8.

Roma, Santa Maria sopra Minerva, capilla de san Luis Bertrán, c. 1671-1674. Foto del autor. tencias, estando como está Su Señoría Illma. de partida para las Indias, y siendo raçonable que dicha capilla no quede en su ausencia sin patrón y protector legítimo poderoso y abonado. Por tanto [...] cede, concede, aplica, assigna y traspassa desde luego para siempre perpetuamente jamás por título y a título de donación pura, perfecta e irrevocable inter vivos y a causa y obra pía al dicho Exmo. Sr. [...] el juspatronato y todo el derecho de patrón y patronato que Su Illma. tiene.

Así, pues, hay que atribuir al obispo González de Acuña la remodelación completa de la capilla de la santa peruana, incluidas la decoración pictórica de Lazzaro Baldi para el altar, los muros laterales y la cúpula ${ }^{34}$. Por el contrario, como ya se ha dicho, la intervención efectuada en la capilla de san Luis Bertrán tuvo un alcance muy restringido (figura 8). Así, los muros laterales, la bóveda y la luneta sobre el altar conservan la decoración antigua. La capilla había sido reformada a instancias del cardenal Scipione [Caffarelli] Borghese hacia I620 y dedicada a santo Domingo, como lo demuestran las pinturas de carácter hagiográfico de dos compartimentos de la bóveda y la desaparecida pala d'altare, una Virgen con el Niño y santo Domingo. Precisamente, uno de los artistas participantes, Gaspare Celio, ofrece información de primera mano: «[...] la pittura del suo Altare con il S. Domenico et li due collaterali, del Cavalier Gioseppe Cesari, il resto di essa Cappella è di Gaspare Celio dell'abito di Christo. Sono tutte ad'olio» ${ }^{35}$. Tratándose de una fuente directa, la información es creíble. Las pinturas «colaterales» que el pintor cita debían enmarcar la tela principal sobre el altar. En cuanto a las de los muros laterales, redescubiertas gracias a una restauración de 1979 - una de ellas reducida a fragmento, la otra con Santo Domingo presentado por la Virgen a Jesucristo-, son las originales de Celio, a quien se atribuyen también los estucos. La pintura sobre tela de la luneta, con la imagen de santo Domingo, así como los dos ángeles 


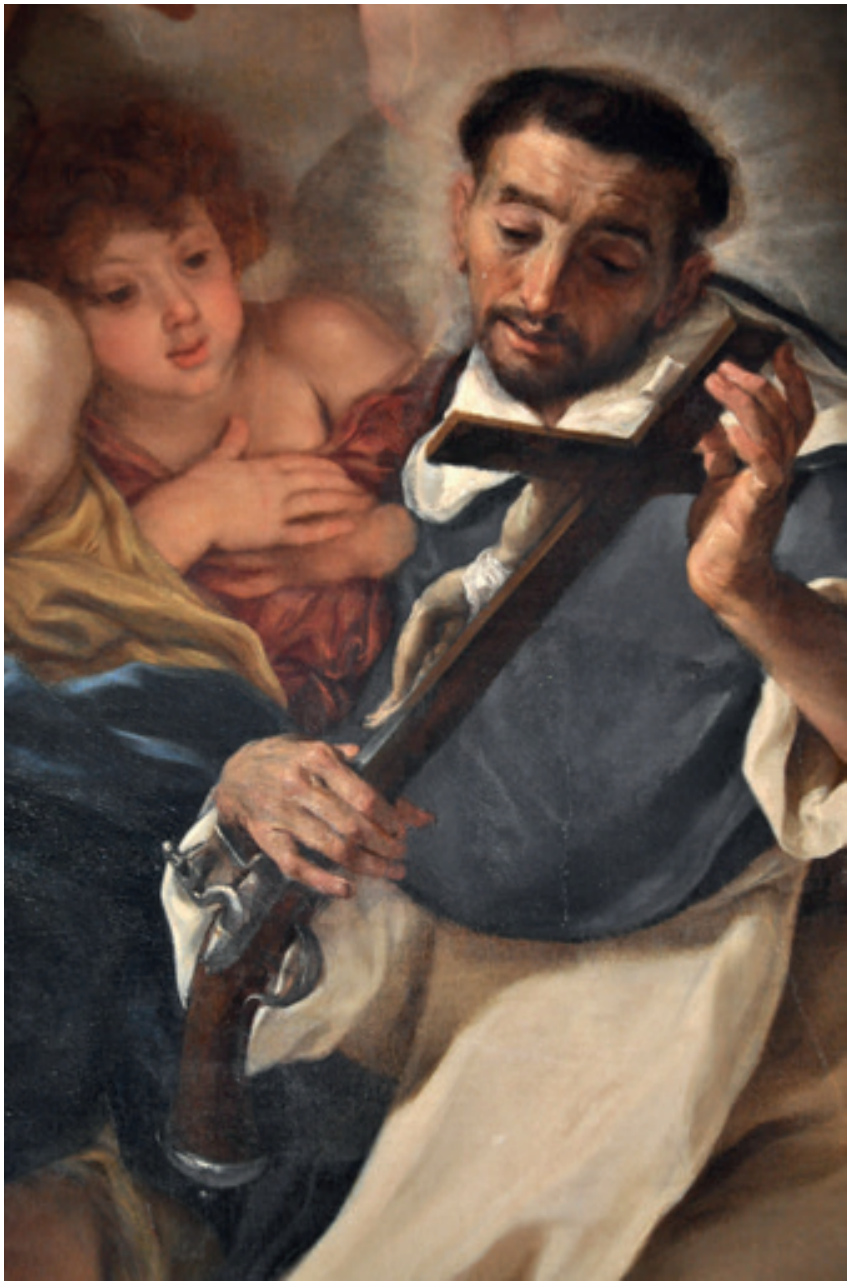

Figura 9

Giovan Battista Gaulli, 1671, San Luis Bertrán (detalle). Santa Maria sopra Minerva. Roma. Foto del autor.

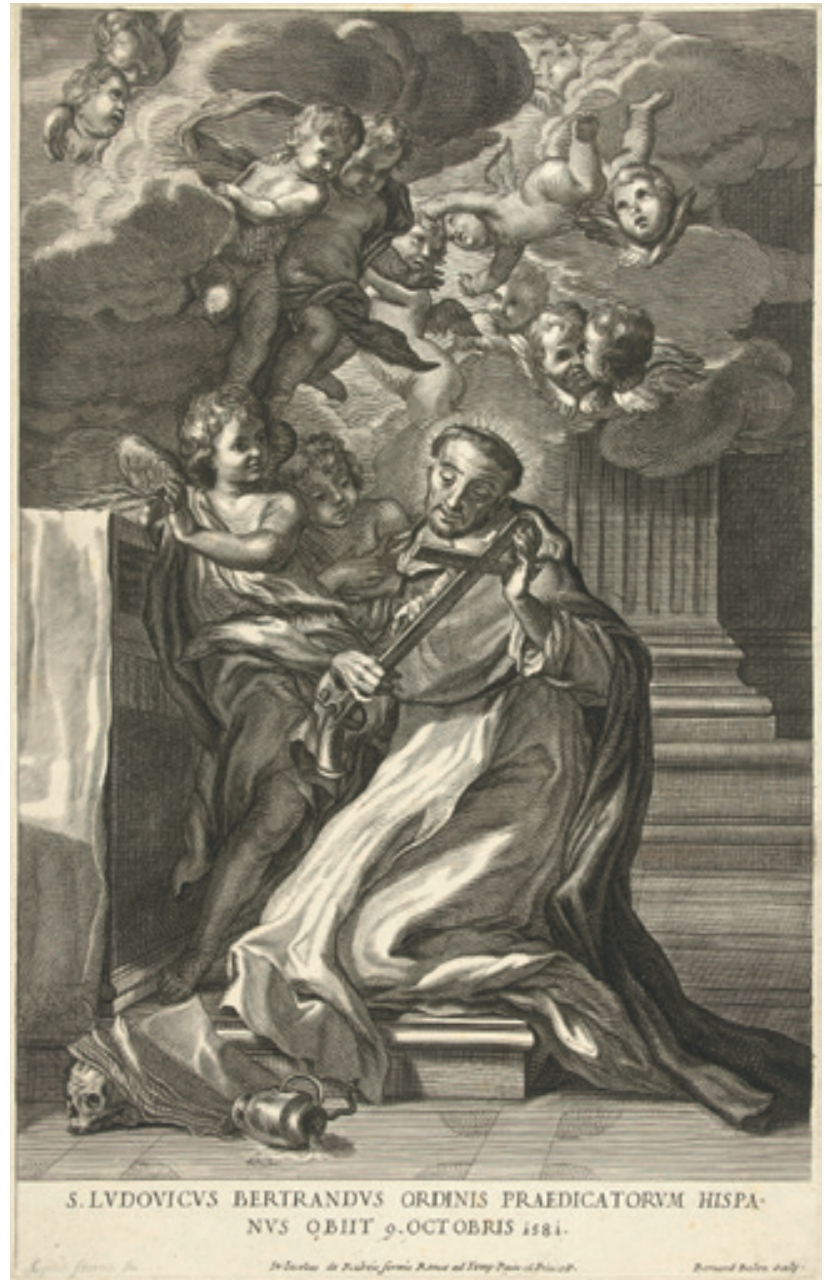

Figura 10.

Giovan Battista Gaulli (diseño), B. de Bailliu (grabado), c. 1671-1674, San Luis Bertrán. pintados al fresco que la enmarcan, son obras anónimas del siglo XVII, aunque el cuadro del fundador a veces se ha identificado con el original del Cavalier d'Arpino ${ }^{36}$.

En su Relatione del sontuosissimo apparato destinado al octavario celebrado en la Minerva en el mes de agosto de i67i para honrar a los dos nuevos santos dominicos, Angelo Martino Listi celebra la renovada capilla de san Luis Bertrán, pero no puede evitar una comparación con la de santa Rosa de Lima, que sale mucho mejor parada ${ }^{37}$ :

Fabricò da fondamenti il predetto Monsignor Gonzales una superbissima capella a S. Rosa, e sapendo l'eroica magnificenza della gran casa Colonna, che ha per uso familiare il partorire le meraviglie, la consegnò alla protettione e Christiana pietà dell'Eccellentiss. Sig. Contestabile Colonna; spicca in questa mirabilmente la generosa divotione di Monsignore nella preciosità delle pietre, nella ricchezza dell'oro e nell'esquisitezza delle pitture, et d'una vaga lampada di cristallo, e fra li bizarri e capricciosi non meno che ingegnosi ornamenti scherza l'erudita intentione dell'Architetto. Parimenti il P. Maestro Lorent ha ornata, e con pietre di valore e antichità di dorati rabeschi, e fregiata di varii miracoli in stucho, la nobil Capella di S. Lodovico del Sig. Duca Caffarelli, alla quale donò un divoto Religioso Converso una rica statua d'argento del Santo.

Por falta de fondos o porque se quiso mantener buena parte de la decoración dedicada a santo Domingo - al menos hasta que este obtuviera otra capilla ${ }^{38}-$, el P. Lorente tuvo que conformarse con una reforma menor, limitada a la incorporación de los mármoles polícromos aún existentes y de unos frisos de estuco con representaciones de milagros del santo («fregiata di varii miracoli in stucho»), que habrá que dar por desaparecidos. Capítulo aparte merece la nueva pala d'altare, encargada a Giovan Battista Gaulli, il Baciccio, sin contar el sólido, y a la 
vez elegante, marco arquitectónico preexistente (figura 9). Hasta el momento, las fuentes documentales no han permitido identificar al cliente. Se ha avanzado que pudo ser un encargo de la familia Altieri, la cual simultáneamente solicitaba los servicios del genovés para la Trinidad de la capilla gentilicia, como ya se ha dicho ${ }^{39}$, pero no hay nada - un escudo, por ejemplo- que lo indique. Y lo mismo puede decirse de los Caffarelli, que, en cambio, marcaron con sus armas la bóveda y la reja. Aparentemente, la opción más probable es la de la orden de predicadores, aunque la nueva documentación que ahora se presenta, esto es, los pagos efectuados por el P. Lorente, no mencionan a Gaulli en ningún momento. Quizá falte algún recibo, o la pintura se pagó con otros fondos, o el P. Lorente no fue responsable del encargo. En cualquier caso, no se pudo actuar sin el consentimiento del $\mathrm{P}$. Rocabertí, un individuo que se implicaba directamente en cuestiones artísticas y, sin duda, también en esta. Por ejemplo, en I 672 se tomó como cosa personal la beatificación de Pío V y organizó el correspondiente octavario en la Minerva, si bien delegando la dirección efectiva de la fiesta en el prior, fray Francesco Giustiniani ${ }^{40}$. No parece casual que la pintura que presidía la rica decoración del interior -incluyendo un laberinto en forma de paisaje, con tres salidas indicadas por los retratos de Clemente X, Carlos II y Mariana de Austria - fuese obra de Lazzaro Baldi, muy activo en la canonización de i67I. El cuadro representaba la Revelación a Pio $V$ de la victoria de Lepanto y se ha identificado con el que ahora cuelga en la capilla del santo de la misma iglesia ${ }^{41}$. Lo que es seguro es que la pintura de Gaulli dedicada a san Luis Bertrán se encontraba en el lugar actual en I674, ya que aparece citada en la famosa guía de Filippo Titi: «La seconda cappella haveva il quadro col Crocifisso e molte figure dipinto da Girolamo Sicciolante, et hora ve n'è un'altro con S. Lodovico Bertrando, opera buona, e diligente di Baciccio Genovese, e diversi fatti di S. Domenico dipinti a olio nelle mura di questa Cappella sono di mano del Cav. Gasparo Celio» ${ }^{42}$. Siempre protegido por Bernini, Gaulli no era inmune a la lección de otros maestros. Hace tiempo que Maria Vittoria Brugnoli observaba en el san Luis Bertrán la influencia de Van Dyck en las armonías sutiles y en las elegantes tipologías físicas $^{43}$. Por su parte, Francesco Petrucci ha recalcado la calidad cromática y los vigorosos valores pictóricos de la tela, sobre todo después de la restauración de que fue objeto entre i999 y 2002. El esbozo - perdido - aparece citado en el inventario del príncipe G. B. Pamphili a inicios del siglo XVIII, mientras que un delicado dibujo preparatorio - solo de los dos ángeles más

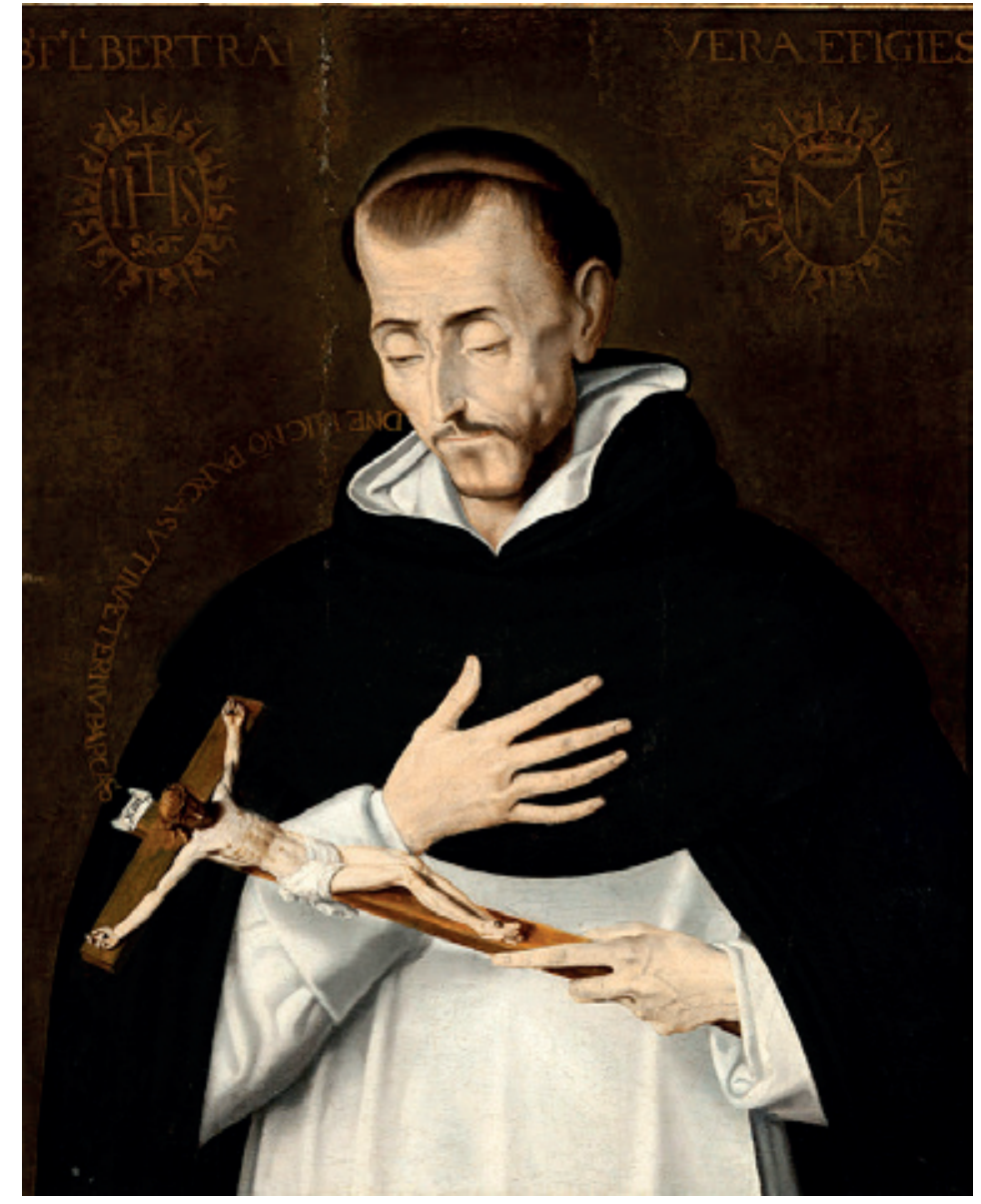

Figura 11.

Joan SarinYena, 1581-1582, San Luis Bertrán. Museo Goya. Colección Ibercaja-Museo Camón Aznar. Zaragoza.

próximos al santo - se conserva en el museo de Berlín (Kupferstichkabinett, inv. KdZ 22407). En el convento de Santa Sabina se conserva una copia procedente de la capilla Elci, que el citado Petrucci atribuye a Giovanni Odazzi, discípulo del Baciccio $^{44}$. La calidad del original explica que fuera rápidamente grabado por Barend de Bailliu (figura io).

En la bella tela del Baccicio también despierta interés la iconografía y, en concreto, el atributo del protagonista. En las primeras representaciones conocidas sostiene con la mano izquierda un crucifijo, mientras que se lleva la otra al pecho con la finalidad de acentuar su faceta más espiritual y contemplativa ${ }^{45}$ (figura I I). Sin embargo, la imagen oficial pensada para la canonización substituye la cruz convencional por otra cuyo brazo longitudinal se transforma en una pistola. Cambia el atributo y cambia el mensaje, ya que se trata ahora de transmitir, en general, la imagen de un prodigio celestial y, en particular, la idea de la concreta intercesión divina a favor del fraile en un intento de atentado, cuando un caballero de Albaida se sintió aludido en un sermón. Es decir, se pone énfasis en la fuerza de la fe y en el poder 


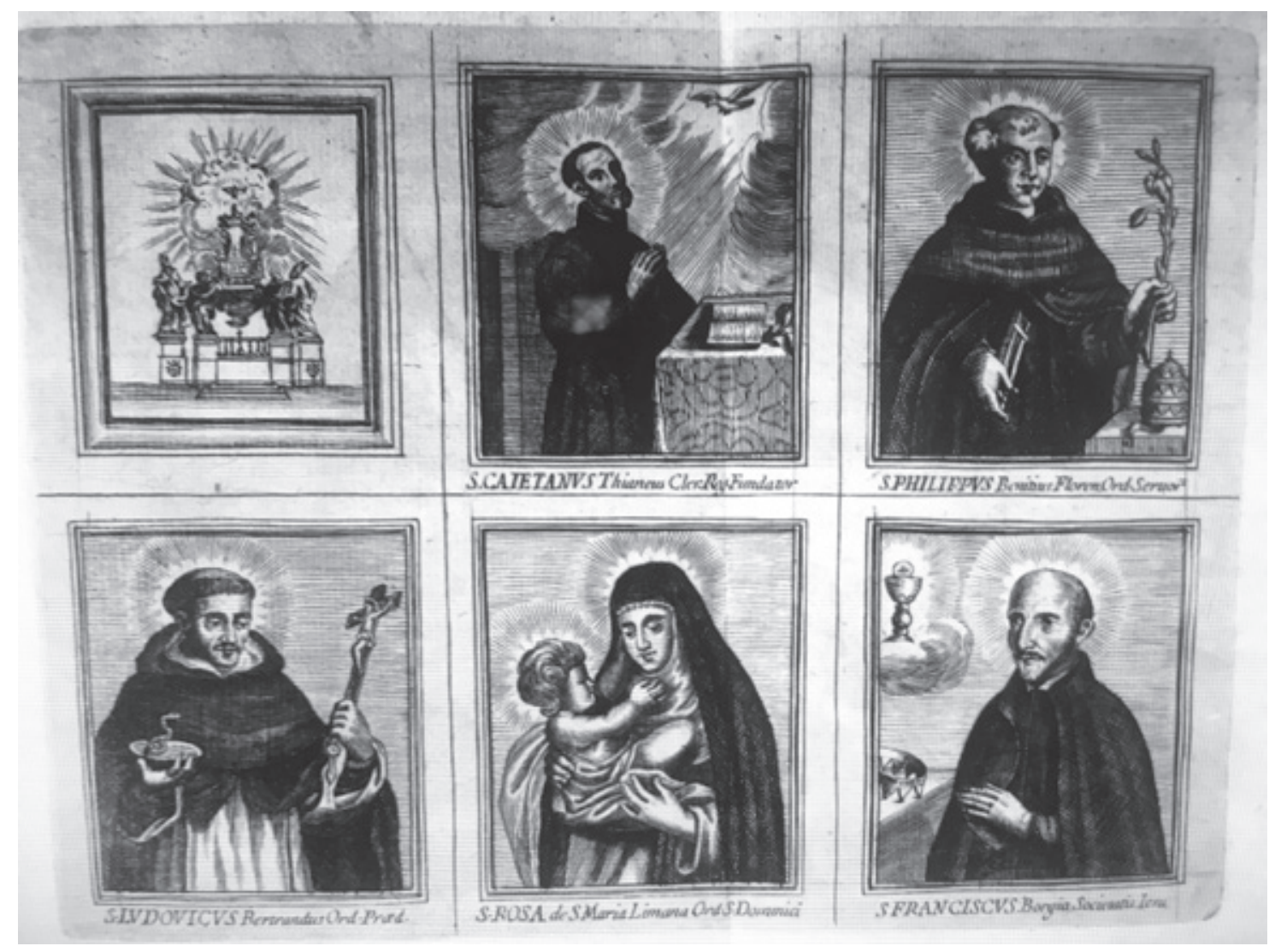

Figura 12.

Relatione delle cerimonie et apparato... Roma, 1671 (ASR, Fondo Cartari Febei, vol. 83). Grabado con los cinco santos canonizados por Clemente X.

protector de la señal de la cruz. Un atributo tan peculiar sorprendía a Émile Mâle, extrañado de que fuese precisamente una pistola transformada en crucifijo el atributo elegido para la imagen reglamentaria del santo en su canonización ${ }^{46}$. El P. Saborit explica la historia ${ }^{47}$ :

Este sucesso es un prodigio muy grande, y de los mayores que Dios ha obrado en la Iglesia por medio de sus Santos, y assí es bien reparemos en las circunstancias dél. Cosa assentada es que los predicadores Evangélicos en sus sermones pretenden y procuran con toda eficacia y cuidado enseñar a sus oyentes la Fe Católica, dándoles reglas y modos como se ha de exercitar en las virtudes y desarraigar los vicios de sus almas, para que muera en ellos el pecado y solo viva Christo en sus coraçones por fe viva [...] Estava duro y empedernido el coraçon del cavallero sobredicho, y assí no hizo efeto en él el sermón, antes quedó indignado contra el Santo predicador, pero él no perdió el amor de Padre espiritual que como predicador Apostólico tenía a aquel oyente [...] y como tenía muy bien sabido el precepto de Christo nuestro Señor y que manda amemos a nuestros enemigos y roguemos por los que nos persiguen y calumnian, devía de ir rogando a Dios por éste, especialmente quando le vió venir para quererle quitar la vida, y assí oyendo Dios la petición de su Siervo, y condescendiendo a sus ruegos, quando hizo la señal de la cruz azia la pistola hizo el poder divino que la pistola se transformase y tomasse forma de cruz con una imagen de Christo crucificado en ella, con que se ablandó aquel coraçón empedernido y quedó gravada la imagen de Christo en su memoria, con lo qual se reduxo a Dios, conoció su culpa y arrepentido pidió perdón de su pecado.

El otro atributo habitual de Luis Bertrán es una copa de la que sale una serpiente, sola como en las versiones de Espinosa y Zurbarán o acompañada del crucifijo pistola como en el grabado que ilustra la Relatione de I67 I (figura I2). Evoca un milagro de la etapa americana, cuando unos indígenas dieron a beber al santo una copa de veneno, que expulsó de su cuerpo al quinto día en forma de reptil. Solo eventualmente sostiene un libro o un lirio y menos frecuente aún es la calavera, más propia de penitentes y ermitaños. Al decidirse por el crucifijo pistola, el iconólogo optó por un atributo original, por no decir extravagante, algo que no se pudo hacer sin un 
debate serio en el seno de la comunidad dominica y seguramente de la Congregación de Ritos. Es cierto que un crucifijo de altar o portátil es un símbolo muy frecuente, sobre todo en el caso de santos de vida contemplativa, y que la copa de veneno la comparten san Juan Evangelista y san Benito de Nursia, pero el santo valenciano se puede distinguir fácilmente por el hábito de su orden. Desde este punto de vista, no había necesidad de alterar la iconografía primitiva, pero tampoco interesó acentuar la faceta evangelizadora, quizá porque a finales del siglo XVII no se consideraba perentoria o porque la Iglesia tenía esta cuota cubierta con otros héroes ${ }^{48}$. El caso es que la imagen definitiva se aleja del estereotipo de santo contemplativo y mortificado - aunque sin eliminar del todo el arrebato extático- a favor de una actitud más reflexiva, que obliga al espectador a interrogarse acerca del significado de un atributo tan insólito. Tal vez quería ser una admonición sobre el peligro de las armas de fuego o de la violencia en general, tal vez un reclamo para realzar un prodigio inaudito, pero no puede ser casual que el episodio del homicio frustrado sea recordado en la bula de canonización, «illico in Crucifixum mirabili transformatione sclopus mutatur», con el consecuente arrepentimiento del agresor y, cosa seguramente más importante, el silencio humilde que el santo impuso sobre el milagro, roto solo treinta años más tarde por uno de los testigos, fray Cristóbal de Mora ${ }^{49}$.

Volviendo al año I671, lo más lógico era que las cuatro órdenes implicadas pagaran la fiesta vaticana de manera conjunta, más o menos equitativamente - los dominicos aportaban dos santos -, a la vez que afrontaban por separado los gastos de las celebraciones particulares. Este tema, el coste de una canonización, aún no ha sido estudiado como se merece. En este sentido son muy interesantes dos relaciones escritas por el abbate Domenico Cappelli (I629-1696), segundo maestro de ceremonias pontificias ${ }^{50}$. La que dedicó a la canonización de Francisco de Sales ( 1665 ) permite conocer los gastos de manera detallada, hasta un total de 31.903 escudos $^{51}$. Para percibir la opulencia desplegada, será suficiente la descripción de la mitra, cubierta de piedras preciosas: «Mitra papalis, velata argentea et distincta centum octoginta duobus adamantibus variae magnitudinis et efformantibus multiplices, variasque figuras, lunulas scilicet et roses: quas insuper insignibant duo zaphiri grandiores, et argentea ligamina». El segundo ejemplo se refiere a la canonización doble de Pedro de Alcántara y Maria Magdalena de Pazzi (I669) ${ }^{52}$. En este caso el coste global ascendió a 64.000 escudos, repartidos a medias ${ }^{53}$. La tradición era antigua, ya que, a finales del siglo XV, se podían gastar entre 25.000 (san Leopoldo de Austria) y 27.000 ducados de oro (san Buenaventura) ${ }^{54}$. En I678, Inocencio XI impuso una cierta moderación. Hay que tener en cuenta que los gastos cubrían también los honorarios de procuradores, jueces, abogados, notarios, médicos, traductores, etc. Las dignidades eclesiásticas solían ser compensadas con una pintura: papa, cardenal nipote, secretarios de la Congregación de Ritos, promotor de la fe, procurador de la causa, etc. El pontífice también recibía una estampa de formato grande (carta grande) y una biografía del santo encuadernada lujosamente. Después de la ceremonia, él mismo distribuía los objetos usados si lo estimaba oportuno: el terno, el frontal de altar, el cáliz de oro, etc. ${ }^{55}$.

La decoración copiosa y una iconografía variada exigían un período de preparación considerable. En el caso que nos ocupa lo demuestran los pagos efectuados a algunos artistas desde I668, tres años antes de la ceremonia oficial. Además, hacía falta tiempo para codificar la imagen normativa del nuevo santo. No siempre se ha puesto suficiente énfasis en el carácter ejemplarizante de la canonización, cénit de un proceso dilatado que exige ineludiblemente la aprobación de las virtudes heroicas del santo y de su capacidad para obrar milagros. Recientemente, Bernadette Majorana - contradiciendo de paso las tesis de Vittorio Casale, la interpretación del cual tilda de ahistórica - defiende que la motivación que inducía al pueblo a participar en este tipo de ceremonia no era la fiesta en sí, la cual por otra parte perpetuaba una fórmula reiterativa, sino los resultados litúrgicos y de comportamiento, espirituales e institucionales de la promoción al culto «[...] gli esiti liturgici e comportamentali, spirituali, istituzionali della promotio ad cultum che delle diverse feste per la canonizzazione dei santi sono in effetti lo scopo) $»^{56}$. Y es que a menudo se presenta este tipo de fiesta poco más que como una simple operación publicitaria, presuntamente destinada por la mercadotecnia vaticana a un público al que hubiera que convencer de doctrinas irresolutas, poco más que un altavoz propagandístico aunque de gran nivel estético. Sin embargo, sin negar la dimensión divulgativa y la carga autocelebrativa de la ceremonia ni el interés cultural y artístico del aparato visual y hagiográfico que la acompaña, la interpretación en clave de propaganda es simplista y en buena parte anacrónica, ya que esconde el verdadero significado teológico y moral del rito y porque tiende a omitir que la ostentación visual iba dirigida a un público predispuesto y de antemano copartícipe. Al final, la variedad específica de la fiesta de canonización se banaliza, confundida en la inmensidad de la categoría genérica de la fiesta barroca. Por ejemplo: ya que el pontífice decreta la veneración universal a un nuevo santo, su defi- 
nición iconográfica no persigue un simple mecanismo de identificación, sino que quiere fijar una imagen sintética o narrativa, depende del caso, que compendie los méritos principales del personaje y transmita valores espirituales edificantes, aleccionadores de un modelo de conducta, bien para asumir determinados comportamientos heroicos, bien para mantener una vida cotidiana virtuosa. Para san Agustín las finalidades de la santidad son claras: el pueblo cristiano celebra unido en solemnidad religiosa la memoria de los mártires para promover la imitación y para solicitar su protección mediante la oración («Populus christianus memorias martyrum religiosa solemnitate concelebrat, et ad excitandam imitationem, et ut meritis eorum consocietur, atque orationibus adiuvetur» $\left.{ }^{57}\right)$. Por otra parte, la canonización era un hecho extraordinario. Cabe recordar que en cuarenta años, a lo largo de los pontificados de Urbano VIII, Alejandro VII y Clemente IX, solo se aprobaron seis casos, además de otros tantos equipolentes, los cuales únicamente generaban fiestas en sus lugares de origen, tales como $\mathrm{Ra}$ món de Peñafort en Barcelona o Fernando III en diferentes ciudades hispanas. Las beatificaciones solo permitían la veneración en iglesias particulares o zonas de influencia. Originaban fiestas en Roma, pero menos ostentosas que las canonizaciones. Es el caso de Pedro Arbués ${ }^{58}$, por citar un ejemplo cronológica y geográficamente próximo.

La logística artística desarrollada para la canonización del i 2 de abril de I67 I tuvo que ser fenomenal, ya que implicaba a múltiples clientes y creadores, además de estar sometida a las intenciones simbólicas y a los requisitos de una liturgia específica y del protocolo impuesto por la curia vaticana. Debido al volumen de trabajo, no todos los artistas podían trabajar para las cuatro órdenes religiosas y, por otra parte, estas debían tener sus preferencias. Además, en los meses siguientes, había que suministrar la decoración destinada a los octavarios celebrados en las iglesias de Sant'Andrea della Valle, Santa Maria sopra Minerva, San Marcello al Corso y el Gesù. Los únicos pintores que trabajaron para las cuatro religiones fueron Lazzaro Baldi y el menos conocido Giovanne Carbone. Un tercer pintor, Alessandro Vasselli, fue contratado por jesuitas y teatinos. En cambio, Carlo Maratti, su copista Francesco Rioli, Luigi Garzi y Nicolò Berrettoni trabajaron solo para los servitas, o esto es lo que se deduce de la documentación hasta ahora exhumada ${ }^{59}$. El caso de Lazzaro Baldi es especial, un auténtico especialista en pintura de canonizaciones, como mínimo entre 1669 y i690. Vittorio Casale se ha interrogado sobre la ubicuidad del artista de Pistoya y, entre los diversos factores que la pueden explicar, resalta la protección de un conterráneo poderoso, el cardenal Flavio Rospigliosi, futuro
Clemente IX: fue este quien impuso a Maratti para el cuadro que los servitas debían regalarle y probablemente quien influyó en las otras órdenes a favor de Baldi. Así pues, el pistoyés era un artista reputado, bastante más de lo que la crítica actual está dispuesta a concederle. El mismo Casale ha calificado de «enfermedad profesional» la fabricación continuada de cuadros de canonización ${ }^{60}$. Estilísticamente, se le considera un pintor de compromiso, en movimiento pendular entre Pietro da Cortona y Carlo Maratti, a veces acusado de ecléctico y poco original, pero siempre eficiente y muy representativo de una pintura con función didáctica y hagiográfica ${ }^{61}$. Por tanto, no puede extrañar que fuera el pintor mejor remunerado en la canonización de san Luis Bertrán: 466 escudos por pinturas que no se detallan ${ }^{62}$, I 40 escudos por el estandarte usado en San Pedro, Ioo escudos por el estandarte usado en Santa Maria sopra Minerva, I 2 escudos por un retrato del santo (tela Imperatoris, es decir, de seis palmos de altura), i 56 escudos por cincuenta y dos copias del mismo que se regalaron a los cardenales (a 3 escudos cada una y, por tanto, de pequeño formato), 7 escudos por otro original (de cuatro palmos de altura) y 5 I escudos por treinta y cuatro copias de este último (a is julios cada una) destinadas a los consultores y otras personas que no se identifican. El recibo se firmó en el domicilio habitual del pintor, en la plaza del Panteón (Platea Rotunda).

En segundo lugar destaca el pintor Giovanni Carbone, que también recibió pagos de los jesuitas y de los servitas. Se encargó de las pinturas de argumento narrativo, colocadas en la parte superior de los intercolumnios de la basílica vaticana. Del P. Lorente recibió 288 escudos y 40 bayocos por obras sin especificar, I 30 escudos por tres estandartes grandes y parte de otro, 83 escudos y 40 bayocos por un cuarto estandarte (todos de diez palmos de longitud, con escudos dorados del Papa, de Carlos II y de la ciudad de Valencia) y 75 escudos por cuatro pinturas apaisadas (longanem) usadas en el Vaticano («inservierunt in Basilica Sancti Petri de urbe pro canoninatione eiusdem sancti Ludovici Bertrandi»). Sorprende el número de estandartes, mucho más crecido de lo que explica la Relatione de la fiesta. Carbone, que también residía en la plaza del Panteón, es un artista poco conocido, el mejor discípulo de Andrea Camassei según Filippo Baldinucci y con poca obra conservada o localizada ${ }^{63}$. Refiriéndose a Camassei, discípulo de Domenichino y Reni, Luigi Lanzi dice «che fa onore alla scuola romana, a cui diede in Giovanni Carbone di S. Severino un allievo di qualche nome» ${ }^{64}$. Como grabador, es autor de una estampa de santa Rosa de Viterbo para la portada de una biografía publicada en castellano en $\mathrm{I}^{6} 5^{65}$. Un tercer pintor 
contratado fue Francesco Ludovisi (Foligno, I635-1715), que cobró 78 escudos por labores decorativas efectuadas en la iglesia minervitana, bien por las telas que cubrían la bóveda, bien por las pinturas narrativas de la fachada. Es considerado un artista de poca categoría, tío de Ludovico Leonini, un librero más conocido ${ }^{66}$. Finalmente, un cuarto pintor, el enigmático Alexio Colino, cobró 50 escudos a través del genovés Giovanni Battita Miralta, en cuya casa residía, por dos cuadros del santo destinados al cardenal Portocarrero, representante del rey en la ceremonia de canonización, y al embajador marqués de Astorga ${ }^{67}$. Los pigmentos para los pintores eran proporcionados por Francesco Reggi y Giovanni Battista Guarnieri, ambos romanos, de profesión colorarius, con tienda abierta en la misma plaza de la Minerva. Los doradores documentados son dos, los hermanos Tommaso y Girolamo Ciriaci, que cobraron una considerable cifra -453 escudos y 40 bayocos - por trabajos realizados en San Pedro. Tenían el taller cerca de la iglesia de San Agostino. El segundo - con grafía «Siriaci» - aparece como responsable del dorado de los marcos de las pinturas de canonización de Francisco de Borja ${ }^{68}$.

Curiosamente, los escultores no fueron solicitados. Solo está documentado el romano Giovanni Barberi, sculptor lignarius, más bien un carpintero, que recibió 47 escudos por un grupo de pequeños objetos usados en la ceremonia de San Pedro: «cadulorum, seu doliolorum, cavearum et aliarum rerum similium», es decir, canastillas, barriletes y jaulas para palomas y tórtolas que se utilizaban en el ofertorio. En este mismo momento se encendían las candelas, que libró el genovés Francesco Grilli por valor de 52 escudos y 60 bayocos («pro laternis et luminibus»). Pero el gasto en cera era ingente: el droguero genovés Giovanni Battista Miralta suministró cera adquirida en Venecia por valor de 896 escudos. En I670 ya había recibido I.400 escudos por la mitad de la cera servida a los jesuitas - entonces el apellido aparece transcrito como Miralto-. Sin embargo, no fue suficiente, de manera que el droguero romano Domenico Valentino tuvo que proporcionar más cantidad, la cual estuvo valorada en 54I escudos y 36 bayocos. Toda esta cera era solo un tercio de la que se consumió. Como era previsible, se encargaron trabajos de orfebrería, aunque no en exceso. Un entallador o cincelador (toreumatum faber), Cristoforo Marchioni, fabricó una imagen del santo por 70 escudos, incluidos los materiales (oro, plata y oricalco). En realidad, se trataba de una medalla, sin duda de tamaño considera$b^{6 e^{69}}$. Sin embargo, si atendemos al precio, 300 escudos, era más relevante la estatua de plata del santo (simulacrum), fabricada por el orfebre ro- mano Camillo del Ponte y regalada al cardenal Paluzzo Altieri, patrono nuncupato.

Capítulo aparte merece la partida destinada a indumentaria litúrgica, una fortuna. Así, Giovanni Battista Bursaglia, vexillorum faber, florentino pero residente en Roma, recibió del P. Lorente la ingente cantidad de 9.676 escudos por el material y las labores textiles: más de dos mil canas de $p a-$ bimito, probablemente un tejido de color violáceo o pavonazzo, y gran cantidad de brocado de seda; cuatro esterillas; la decoración y las cenefas de las cortinas confeccionadas con dicho pabimito; los baldaquinos usados en San Pedro, las cortinas, la pasamanería y el encaje, la ropa litúrgica del pontífice, la fabricación de los estandartes, etc. Pero lo más sorprendente es que el P. Lorente solo se hacía cargo de una tercera parte de los gastos totales en esta materia, lo que eleva la cifra total a cerca de 30.000 escudos. No sabemos si Bursaglia trabajó para totas las religiones, pero sí para los jesuitas, que le pagaron por telas de damasco algo más de 8.442 escudos $^{70}$. Aparte, el bordador romano Agostino Banchieri fabricó la mitra papal con las armas correspondientes y otras labores de bordado. El P. Lorente pagó I.067 escudos y 97 bayocos, que solo cubrían la tercera parte del to$\mathrm{tal}^{71}$. Sin llegar a estas cifras tan considerables, el resto del dispendio no fue menor: Giovanni Andrea Bessi cobró 250 escudos por la parte proporcional de los fuegos artificiales lanzados durante el octavario ${ }^{72}$; el Rdo. Nicolás Estameña, maestro de capilla de Santiago de los Españoles, 366 escudos por la parte correspondiente a la música interpretada en la basílica vaticana, en la procesión de los estandartes y durante el octavario de los dos santos dominicos ${ }^{73}$; el impresor de grabados (imaginum et effigierum impressor) Francesco Columbo, 60 escudos por diversas estampas del santo, y el editor Niccolò Angelo Tinassi, 300 escudos por imprimir una biografía, probablemente la de Leandro Colloredo.

Prácticamente tota esta producción artística debe darse por desaparecida. En parte esto estaba previsto, ya que algunos elementos eran diseñados para tener una vida efímera, fabricados con materiales perecederos, o bien el sobrante era reciclado, como pasaba con la cera no consumida. Esto es válido también, o especialmente, para la decoración de la fachada y del interior de la iglesia minervitana, que conocemos virtualmente gracias a la correspondiente Relatione, la cual incorpora además dos grabados que reproducen la fachada principal y el altar de santa Rosa de Lima. El primero es obra de G. B. Sendergelt, con dibujo del anteriormente citado fray Giuseppe Paglia, mientras que el segundo está firmado por G. B. Falda ${ }^{74}$. El narrador explica que la iniciativa fue de los procuradores de ambas causas pías, el obispo González de Acuña y el P. Lorente. El 


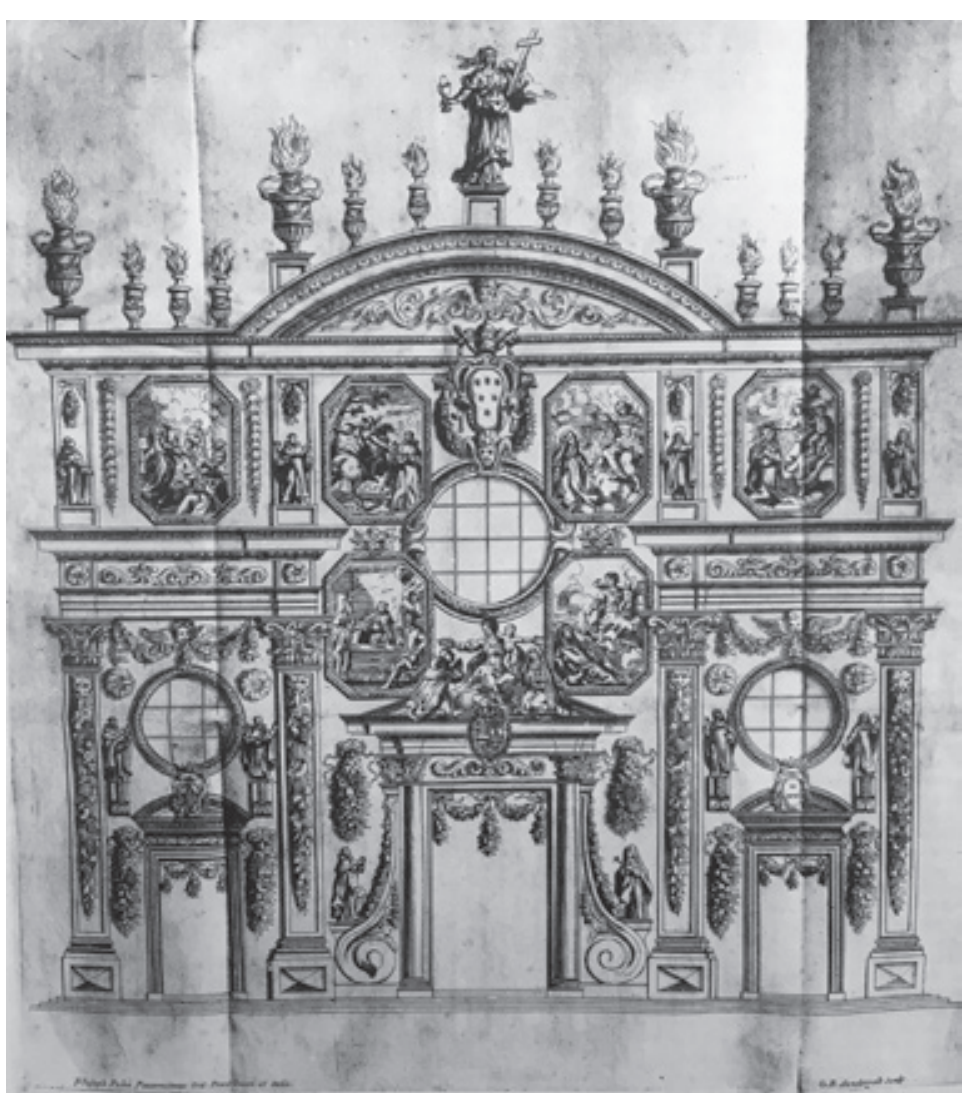

Figura 13.

Giuseppe Paglia (diseño y dibujo), G. B. SENDERgelt (grabado), 1671, decoración efímera de la fachada de Santa Maria sopra Minerva de Roma para la fiesta de canonización de san Luis Bertrán y santa Rosa de Lima. De la Relatione del suntuosissimo apparato... Roma, 1671 (ASR, Fondo Cartari Febei, vol. 83).

octavario comenzó el 4 de agosto, festividad de santo Domingo de Guzmán (desde i 568 hasta hace poco se celebraba ese día), con la procesión solemne de los estandartes desde San Pedro hasta Santa Maria sopra Minerva, sostenidos por obispos y otras dignidades eclesiásticas. Participaron diversas cofradías, más de cuatrocientos nobles romanos presididos por Domenico Colonna, sesenta prelados y una muchedumbre. Como es de suponer, muchas casas del itinerario estaban engalanadas con sedas y brocados. A la puerta del templo dominico la comitiva fue recibida por el cardenal nipote Altieri, nombrado nuevo protector de la orden. Los días siguientes se cantaron misas y se pronunciaron los sermones habituales. También era costumbre que se lanzasen fuegos artificiales en la Piazza Navona para inaugurar y cerrar el octavario. La iglesia fue visitada por una multitud, de la que destacaba la presencia de los embajadores de España, Portugal y Venecia, del P. Everardo Nithard, de la reina de Suecia, de los príncipes Altieri, de la duquesa de Gravina, etc. El día más señalado fue sin duda el domingo 9 de agosto, cuando acudieron el papa y el colegio de cardenales, los cuales fueron regalados con dos ejemplares del resumen biográfico y diversas imágenes (dos medallas, dos figuras in raso y dos in carta, es decir, grabadas sobre seda y sobre papel) de los nuevos canonizados.

El tracista del aparato decorativo era, una vez más, Giuseppe Paglia (figura I3). La iconografía de la fachada era compartida por los dos nuevos santos, sin contar el añadido de algunas estatuas doradas de beatos y beatas de la orden, sin identificar, y de la alegoría de la Religión en el remate. El narrador alude a cuatro medallones con milagros de los santos, pero sorprendentemente aparecen seis en el grabado. En todo caso, las escenas más importantes estaban constituidas por un grupo escultórico de la Virgen con el Niño coronando a los santos Luis Bertrán y Rosa de Lima, sobre la puerta principal, y tres pinturas de formato octogonal y carácter narrativo dedicadas a cada santo. Las correspondientes a san Luis representaban su muerte, el milagro de la pistola convertida en crucifijo y el milagro del pan que sangra. Este último es un argumento poco conocido, pero de contundente función didáctica: era la respuesta del santo a un militar arrogante, para darle a entender que sus riquezas eran la sangre de los pobres. La decoración del interior del templo se dividía en dos partes. Por un lado, la nave central quedaba aislada de las laterales mediante grandes telas que colgaban de los capiteles (terciopelos carmesíes y dorados) y de la cornisa (veinticuatro damascos con bordados de oro y en el centro imágenes de beatos dominicos); la bóveda estaba cubierta con telas pintadas, «da erudito penello", con putti que sostenían festones de flores y escudos del rey de España, del protector de la orden y de las ciudades de Valencia y Lima. Por otro lado, en el coro se levantaba el teatro: el primer prospetto se articulaba con dos órdenes de columnas imitando piedra y - en la base y el capitel- metal, los cuales enmarcaban diversos arcos, dejando un espacio central para las figuras alegóricas de Europa y América y, rematando el conjunto, media docena de vasos llenos de flores y una cruz; después, una serie de arcos sostenían una gloria iluminada con setecientas velas donde los dos nuevos santos eran presentados a la Virgen con el Niño por san Vicente Ferrer y santa Catalina de Siena, todo sobre una nube de oro.

Gracias al P. Lorente, el estandarte principal y cinco cuadros usados en la iglesia de la Minerva, además de un terno y algunos ornamentos de plata - quizá reaprovechados de la ceremonia de San Pedro-, se mandaron a Valencia. Lo explica el P. Vidal Micó, biógrafo del santo y vicario general de la provincia de Aragón ${ }^{75}$ :

Por abril del año 1672 se pusieron sobre la Puerta de la Iglesia [de Santo Domingo de Valencia] los cinco quadros pintados al temple con los Milagros de S. Luis (que oy están 
en la Portería) y sirvieron en el Convento de la Minerva de Roma en las Fiestas de la Cagonización [sic] del Santo, y se pagaron de su dinero; los traxo de Roma el Padre Maestro Fr. Pedro Lorente, Procurador de la Causa. También traxo de Roma un Pendón de tafetán encarnado, y en la una y otra parte pintado S. Luis subiendo al Cielo acompañado de Ángeles, y con instrumentos músicos. En las solemnidades de las Canonizaciones se acostumbra hazer estos pendones, y uno de ellos se dexa en Iglesia de San Pedro de Roma, y otro se da a la Iglesia a donde pertenece el Santo canonizado, y ay muchas Indulgencias concedidas a los que siguen la Procesión que se haze llevando en ella solemnemente el Pendón. Un terno y otras alhajas preciosas traxo también de Roma el padre Maestro.

Estas pinturas no deben confundirse con las que Jerónimo Jacinto Espinosa, gran devoto del santo, pintó para la capilla del convento valenciano entre I653 y I655, y que actualmente son propiedad del Museo de Bellas Artes de la misma ciudad ${ }^{76}$. Por otra parte, habrá que tener paciencia para comprobar si por casualidad alguna de aquellas obras ha podido conservarse en la casa natal del santo, ahora de propiedad particular e inaccesible. El interior ha sido muy modificado, pero parece ser que aún aloja cuatro pinturas sobre tela que representan escenas de la vida de san Luis Bertrán (I 57 x 220 cm), atribuidas en alguna ocasión a un anónimo pintor de escuela valenciana de finales del siglo XVII, pero que nadie ha podido estudiar ${ }^{77}$.

Por suerte, se ha localizado una de las pinturas de Lazzaro Baldi que, en I67 I, se usaron en la ceremonia de San Pedro (Roma, antigua colección Rospigliosi, en la actualidad Confederazione Nazionale Coltivatori Diretti). Identificada por Vittorio Casale en I979, lleva por título Milagro de la cruz incisa en el árbol (figura I4), un asunto que tuvo bastante repercusión. Sin ir más lejos, era el tema de uno de los citados cuadros de Espinosa, de gran formato (405 $\mathrm{x}$ $333 \mathrm{~cm}$ ). También fue reproducido en grabado, tal como el de Benoît Thiboust según un original de Domenico Rainaldi, impreso en Roma en I 668 y dedicado por el P. Favores al marqués de Astorga ${ }^{78}$. La cruz quedó grabada en el árbol después de que el santo lo abrazase, un portento que inspiró la conversión inmediata de los aborígenes de un poblado colombiano. La composición diseñada por Baldi acentúa el formato vertical del cuadro con la elevación gradual de los personajes: san Luis que señala el árbol, su compañero fray Jerónimo Fernández, el jefe de la tribu y un grupo de indios, más exóticos en la versión de Espinosa que en la del italiano. Al

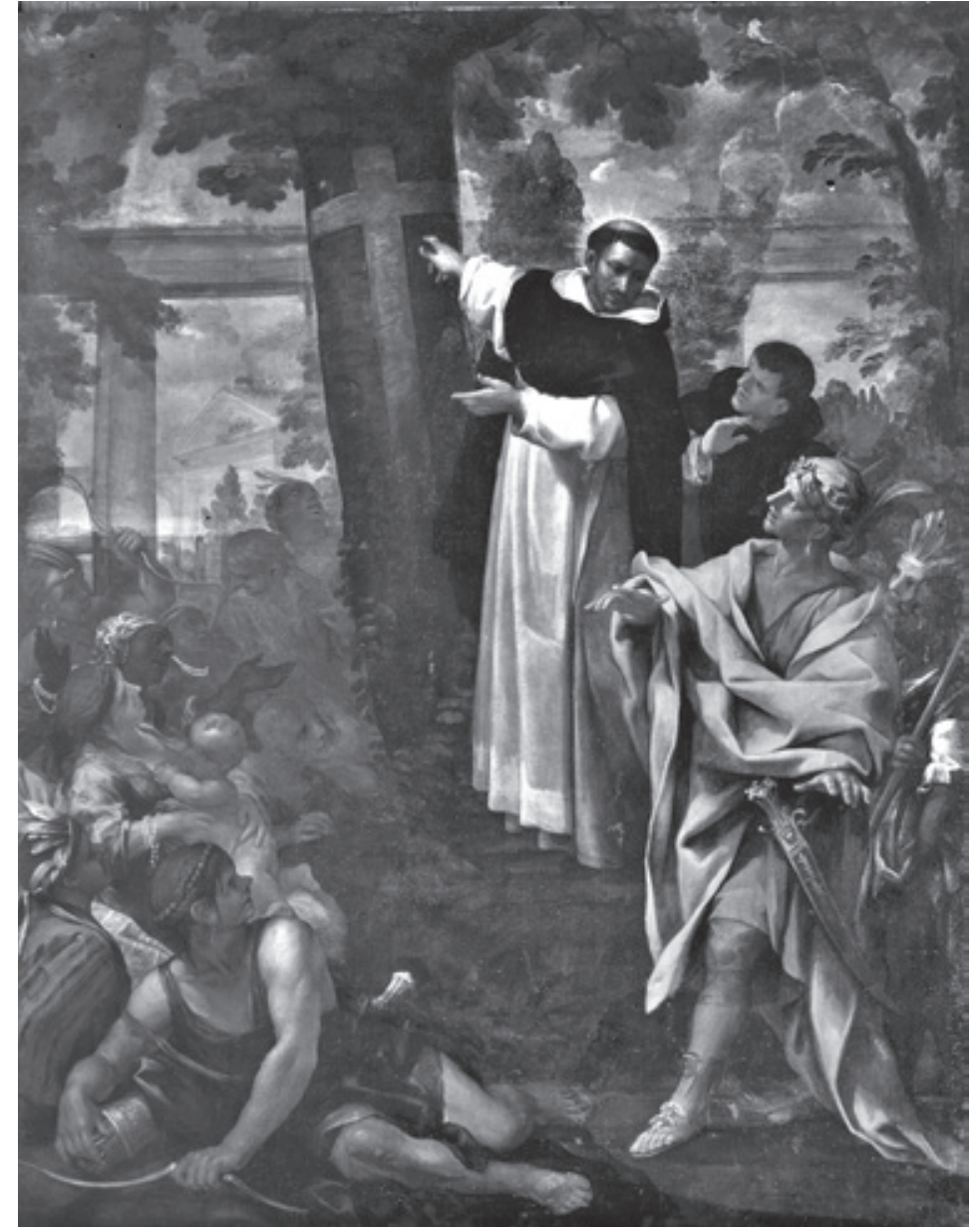

Figura 14.

Lazzaro BALDI, 1671, Milagro de la cruz incisa en el árbol. Roma, Coldiretti (antigua colección Rospigliosi). Por concesión de la Fototeca della Fondazione Federico Zeri, agotados los derechos patrimoniales del autor.

fondo del paisaje selvático se adivina una iglesia de perfil clásico. Angela Negro ha remarcado el cortonismo de Baldi y la atmósfera evocadora y romántica que desprenden el paisaje y los tonos intensos y tostados de la fase madura del pintor. Apunta, además, que la monotonía progresiva de la abundante producción devocional de Baldi es aquí redimida por los detalles narrativos, las fisonomías variopintas, la indumentaria y el armamento de los indígenas. En definitiva, por el toque teatral en una pintura de evidente finalidad didáctica. La obra fue regalada a Clemente IX, a la muerte del cual pasó al cardenal nipote Giacomo Rospigliosi. Aparece en el inventario del príncipe G. B. Rospigliosi de I7I3: «Un quadro in tela di p. 8 e I 2 in circa [...] rappresenta San Ludovico Beltrame che mostra una Croce ad un Rè in un arboro con molte figure. Lazzaro Baldi». No era la única imagen del valenciano en manos de la familia, ya que también poseía «un quadro in tela da Imperatore [...] rappresenta S. Ludovico Beltrame Domenicano con Crocefisso in mano che fa pistola» ${ }^{79}$. 


\section{Apéndice documental ${ }_{1}^{80}$}

Archivio Storico Capitolino di Roma (ASCR), Archivio Generale Urbano, Sez. I, vol. 632, not. J. A. Redoutey, s.f.

\section{Die I4 septembris anni I67I}

In mei [praesentia personaliter constitutus], Joannes Carbone Pictor Tolentinensis Diocesis, filius quondam Francisci, Romæ degens, mihi [notario] cognitus, sponte ac omnibus confessus fuit habuisse et recepisse partim in contanti et partim vigore mandatis seu ordinis directi Ministris Banchi Sancti Spiritus de Urbe ab admodum R. P. M. fr. Petro Lorente Ordinis Predicatorum, Procuratore in hac Curia pro Canonizatione Sancti Ludovici Bertrandi eiusdem Ordinis presente, stipulante, et acceptante scuta ducenta et octuaginta octo, et baiocchos quadraginta monetæ romanx, de juliis decem pro quolibet scuto, huiusmodi in hunc qui sequitur modum, nempé, scuta centum et triginta similia pro pictura et confectione per eum facta trium toreumatum maiorem et unius partis alterius toreumatis, scuta octuaginta tria et baiochos quadraginta similia pro pictura seu confectione aliorum quatuor toreumatum continentia decem palmorum unumquodque illorum, decem impressionum depictarum de claro et scuto aureo miniato Armorum D. N. Papæ, Regis Catholici et Civitatis Valentinensis, et scuta septuaginta quinque etiam similia pro confectione et mercede quatuor picturarum longarum qux et omnia supra contenta inservierunt in Basilica Sancti Petri de Urbe pro Canonizatione eiusdem Sancti Ludovici Bertrandi, ascendentes supra recensitx summæ ad dicta ducenta et octuaginta octo scuta et baiochos quadraginta, de quibus idem Joannes Carbone se benè contentum et satisfactum vocavit, et ad ulteriorem cauthelam exceptioni, speique etc. renunciavit, quietavit etc. per pactum etc. super quibus etc. Actum Rome in domo solite habitationis eiusdem Joannis Carbone sita in Platea Rotunda Regionis eiusdem, seu alterius cuiusvis, presentibus DD. Nicolao Ghiriaggi et Francesco Ghiriaggi dicta Tolentinensis Diocesis, fratribus germanis, filiis domino Pauli, Romæ residentibus, testibus et rogatis. Jacobus Ant. Redoutey not.

\section{Dicta die}

In mei etc., Franciscus Reggi Romanus colorarius, filius quondam Placidi, Romæ degens, mihi etc. notus, sponte, ac omnibus confessus fuit habuisse et recepisse partim in contanti et partim vigore ordinis directi Ministris Banchi Sancti Spiritus de Urbe ab admodum R. P. M. fr. Petro Lorent ordinis Predicatorum, Procuratore in hac Curia pro Canonizatione Sancti Ludovici Bertrandi eiusdem ordinis presente, stipulante et acceptante scuta quatuordecim monetæ Romanæ de juliis decem pro quolibet scuto huiusmodi pro solutione laternarum maiorum per eum prestitarum et venditarum pro celebratione festorum canonizationis dicti Sancti Ludovici Bertrandi in ecclesia Sanctx Marix supra Minervam de Urbe facta, ascendente ad dicta scuta quatuordecim, de quibus idem Franciscus Reggi se benè contentum et satisfactum vocavit et ad ulteriorem cauthelam exceptioni speique etc. per pactum etc. super quibus etc. Actum Romæ in domo solitæ habitationis eiusdem Francisci Reggi sita in Platea Sanctæ Mariæ supra Minervam, Rotunde seu alterius cuiusvis Regionis, presentibus Carlo Bagnoli Romano, filio quondam Francisci, et Domenico Filidoro etiam Romano, filio quondam Basilii, Romæ residentibus, testibus et rogatis. Jacobus Ant. Redoutey not.

\section{Die qua retro}

In mei etc., Joannes Baptistam Guarnieri Romanus colorarius, filius quondam Christophori, Romæ degens, mihi etc. cognitus, sponte ac omnibus confessus fuit habuisse et recepisse vigore ordinis directi Ministris Banchi Sancti Spiritus de Urbe ab admodum R. P. M. fr. Petro Lorent ordinis Predicatorum, Procuratore in hac Curia pro canonizatione Sancti Ludovici Bertrandi eiusdem ordinis presente, stipulante et acceptante scuta triginta monetæ Roman $x$, de juliis decem pro quolibet scuto huiusmodi pro solutione laternarum maiorum per eum prestitarum et venditarum pro celebratione festivitatis noctuum canonizationis eiusdem Sancti Ludovici ascendentes ad dicta triginta scuta, de quibus idem Joannes Baptista Guarnieri se benè contentum et satisfactum vocavit et ad ulteriorem cauthelam exceptioni, speique etc. per pactum etc. super quibus etc. Actum Romæ in domo solite habitationis eiusdem Joannes Baptistx sita in Platea Sanctæ Mariæ supra Minervam, Rotunde seu alterius cuiusvis Regionis, presentibus Paulo Fabi Spoletanensis Diocesis, filio D. Francisci, et Bernardino Mancinelli Viterbensis Civitatis, filio quondam Domenici, Rome residentibus testibus et rogatis. Jacobus Ant. Redoutey not.

\section{Die qua retro}

In mei etc., D. Lazarus Baldi Pictor Pistoriensis Diocesis, filio quondam Joannes Baptistx, Rome degens, mihi etc. notus, sponte ac omnibus confessus fuit habuisse et recepisse partim in contanti et partim unius ordinis directi Ministris Banchi Sancti Spiritus de Urbe ab admodum R. P. M. fr. Petro Lorent ordinis Predicatorum procuratore in hac Curia pro canonizatione Sancti Ludovici Bertrandi eiusdem ordinis presente, stipulante et acceptante scuta quadringenta et sexaginta sex monetx Romanx, de juliis decem pro quolibet scuto huiusmodi pro solutione picturarum per eum factas pro celebratione canonizationis eiusdem Sancti Ludovici Bertrandi in hunc qui sequitur modum, videlicet, scuta centum et quadraginta similia pro pictura vexilli maioris quod inserviit in Basilica Sancti Petri de Urbe, centum alia scuta etiam similia pro pictura alterius vexilli quod inserviit in ecclesia Sanctæ Marix supra Minervam, scuta duodecim similia 
pro uno originali effigiei eiusdem Sancti Ludovici Bertrandi in tela Imperatoris, centum et quinquaginta sex scuta similia pro quinquaginta duabus copiis dicti originalis qux inservierunt pro Emmis. et Rmis. DD. Cardinalibus ad rationem trium scutorum qualibet illarum, scuta septem pro altero originali quatuor palmorum, et quinquaginta unum scuta pro triginta quatuor copiis dicti originalis ad rationem juliorum quindecim pro qualibet illarum qux inservierunt pro Consultoribus et aliis personis, ascendentes supra recensitæ summæ ad dicta scuta quadringenta et sexaginta sex monete presente, de quibus idem D. Lazarus Baldi se benè contentum et satisfactum vocavit et ad ulteriorem cauthelam exceptioni, speique etc. per pactum etc. super quibus etc. Actum Romæ in domo solitæ habitationis eiusdem D. Lazari Baldi sita in Platea Rotundx Regionis eiusdem seu alterius cuiusvis presentibus DD. Petro Paulo Leonardi et Joanne Baptista Leonardi, fratribus germanis Romanis filiis D. Sebastiani, Romæ residentibus, testibus ad præmissa et rogatis. Jacobus Ant. Redoutey not.

\section{Dicta die}

In mei etc., Christophorus Marchioni Romanus [al margen: filius quondam Pauli] Toreumatum faber sub signo Lupx, Romæ degens, mihi etc. notus, sponte ac omnibus confessus fuit habuisse et recepisse in contanti in pluribus et diversis vicibus ab admodum R. P. M. fr. Petro Lorent ordinis Predicatorum, Procuratore in hac Curia pro canonizatione Sancti Ludovici Bertrandi eiusdem ordinis [al margen: presente, stipulante et acceptante] scuta septuaginta monetx Romanx de juliis decem pro quolibet scuto huiusmodi pro solutione toreumatum [al margen: effigiei dicti Sancti Ludovici Bertrandi] tam auri, argenti, quam oricalchi in illius Apotheca emptorum, ascendente ad dicta septuaginta scuta, de quibus ipse Christophorus Marchioni se benè contentum et satisfactum vocavit et ad ulteriorem cauthelam exceptioni, speique etc. renunciavit, quietavit, etc. per pactum etc. super quibus etc. Actum Romæ in domo solite habitationis dicti Christophori sub signo Lupæ sita in via Coronariorum Pontis seu alterius cuiusvis Regionis, presentibus DD. Josepho Cartonio Romano, filio quondam Joannis Francisci, et Valentino Vincentio Rè, Romano, filio D. Claudii Romæ residentibus testibus et rogatis. Jacobus Ant. Redoutey not.

\section{Die qua supra}

In mei etc., Franciscus Grilli Januensis Civitatis, filius Balthazaris, candelarius sebaceus, Romæ degens, mihi etc. notus, sponte ac omnibus confessus fuit habuisse et recepisse in contanti in pluribus et diversis vicibus $\mathrm{ab}$ admodum R. P. M. fr. Petro Lorente ordinis Predicatorum, Procuratore in hac Romana Curia pro canonizatione Sancti Ludovici Bertrandi presente, stipulante et acceptante scuta quinquaginta duo et baiochos sexaginta monetæ Romanæ de juliis decem pro quolibet scuto huiusmodi pro candelis sebaceis qux inservierunt pro laternis et luminibus consumptis in diebus canonizationis et festivis eiusdem Sancti Ludovici Bertrandi qux ascendunt ad dicta quinquaginta duo scuta et baiocchos sexaginta, de quibus idem Franciscus Grilli se benè contentum et satisfactum vocavit et ad ulteriorem cauthelam exceptioni, speique etc. renunciavit, quietavit etc. per pactum etc. super quibus etc. Actum Romæ in domo solitx habitationis eiusdem Francisci Grilli sita in Platea Rotundæ Regionis eiusdem seu alterius cuiusvis, presentibus Andrea Gagino Mediolanensis Diocesis, filio Bartholomei, et Antonio Alberti Romano, filio Francisci, Romæ residentibus testibus et rogatis. Jacobus Ant. Redoutey not.

\section{Die Is septembris I67I}

In mei etc., Joannes Andreas Bessi Romanus filius quondam Mathiae librator Arcis Sancti Angeli huius civitatis Romæ ibi degens, mihi etc. notus, sponte ac omnibus confessus fuit habuisse et recepisse partim in contanti et partim in unius ordinis directi Ministris Banchi Sancti Spiritus de Urbe ab admodum R. P. M. fr. Petro Lorente ordinis Predicatorum, Procuratore in hac Romana Curia pro canonizatione Sancti Ludovici Bertrandi presente, stipulante et acceptante scuta ducenta et quinquaginta monetæ Romanæ de juliis decem pro quolibet scuto huiusmodi pro rata parte mercedis ei debita ab eodem admodum R. P. M. fr. Petro Lorent pro ignibus artificialibus factis die festivo eiusdem Sancti Ludovici Bertrandi et Sanctæ Rosæ de Sancta Maria Limanx in ecclesia S. Mariæ supra Minervam et illius octava durante, ascendentes ad dicta centum et quinquaginta scuta pro parte ad dictum R. P. Procuratorem spectanti de quibus idem Joannes Andreas Bessi se benè contentum et satisfactum vocavit et ad ulteriorem cauthelam exceptioni, speique etc. renunciavit, quietavit, etc. per pactum etc. super quibus etc. Actum Romæ in domo mei infrascripti notarii in Regione Campi Martii sita, presentibus DD. Stephano Gaillard Bisuntinx Diocesis, filio quondam Claudii, et Petro Maria Martini Clerico Romano, filio quondam Claudii, Romæ residentibus testibus et rogatis. Jacobus Ant. Redoutey not.

\section{Die 24 septembris I67I}

In mei etc., Joannes Baptista Bursaglia vexillorum faber florentinus, filius quondam Petri Joannis Romæ degens, mihi etc. notus, sponte ac omnibus confessus fuit habuisse et recepisse partim in contanti in pluribus et diversis vicibus et partim in unius ordinis directi Ministris Banchi Sancti Spiritus de Urbe et aliorum ab admodum R. P. M. fr. Petro Lorente ordinis Predicatorum, Procuratore in hac Romana Curia pro canonizatione Sancti Ludovici Bertrandi presente, stipulante et acceptante scuta novem millia sexcenta septuaginta sex monetæ Romanæ de juliis decem pro quolibet scuto huiusmodi in hunc qui siquitur modum videlicet pro tertia parte qux ad ipsum R. P. Procuratorem spectavit solvere tanquam talem partem duorum millium centum sexaginta novem cannarum pabimiti scuta quatuor millia quadringenta quinquaginta septem similia et baiochos triginta novem, pro tertia parte panni sericei vulgo brocato qui inserviit pro confectione Baldachini in Basilica Sancti Petri pro celebratione canoniza- 
tionis Sancti Ludovici Bertrandi [al margen: et aliorum quatuor storearum] scuta trecenta quinquaginta septem et baiochos triginta tres eiusdem monetæ, pro tertia parte trinae qua fuerunt ornata peristromata ex pabimito facto, fimbriarum dictorum peristromatum, Baldachini de brocato, tunicae et ornamentum Summi Pontificis, passamani et merletti tria millia sexcenta nonaginta quatuor scuta similia et baiochos nonaginta quatuor cum dimidis, pro tertia parte Nobilitatis pro ornatu et opere phrygio scuta sexaginta duo similia, pro tertia parte taffetani et variarum telarum pro foderam in ibus scuta centum triginta quinque etiam similia et baiochos quindecim cum dimidio, pro tertia parte cingulorum, funiculorum sericeorum floccorum et pistorum sericeorum et ex auro pro ornamentum Summi Pontificis scuta octuaginta quinque etiam similia et baiochos viginti, pro tertia parte variarum rerum centum et quindecim scuta similia et baiocchos quinquaginta tres cum dimidio, pro tertia parte operorum ornamentorum Papæ Baldachinorum et Peristromatum scuta ducenta septuaginta et baiochos viginti septem [...], pro tertia parte albidinis scuta ducenta triginta sex similia et baiochos nonaginta septem, et pro tertia parte vexillorum scuta etiam similia ducenta sexaginta duo et baiochos viginti cum dimidio, ascendentes supra recensitæ summæx ad dicta scuta novem millia sexcenta septuaginta sex de quibus idem D. Joannes Baptista Bursaglia se benè contentum et satisfactum vocavit et ad ulteriorem cauthelam exceptioni, speique etc. renunciavit, quietavit, etc. per pactum etc. super quibus etc. Actum Romæ in Domo professa Societatis Iesu, presentibus Domenico Agostino Tiburtinensis Diocesis, filio quondam Simonis, et Thoma Torti Florentinensis Diocesis, filio quondam Hieronimus, Romæ residentibus testibus et rogatis. Jacobus Ant. Redoutey not.

\section{Die 27 septembris I67I}

In mei etc., D. Franciscus Ludovisius Pictor Fulginatensis Diocesis, filius quondam Ludovici, Romæ degens mihi etc. notus, sponte ac omnibus confessus fuit habuisse et recepisse partim in contanti et partim in unius ordinis directi Ministris Banchi Sancti Spiritus de Urbe ab admodum R. P. M. fr. Petro Lorent ordinis Predicatorum, Procuratore in hac Curia pro canonizatione Sancti Ludovici Bertrandi eiusdem ordinis presente, stipulante et acceptante scuta septuaginta octo monetæ Romanx de juliis decem pro quolibet scuto huiusmodi pro mercedis solutione picturarum per eum factarum pro diebus festivis eiusdem Sancti Ludovici Bertrandi celebratis in ecclesia S. Mariæ supra Minervam, ascendentes ad dicta scuta septuaginta octo de quibus dictus D. Franciscus Ludovisius se benè contentum et satisfactum vocavit et ad ulteriorem cauthelam exceptioni, speique etc. renunciavit, quietavit, etc. per pactum etc. super quibus etc. Actum Romæ in domo solitx habitationis mei infrascripti notarii in Regione Campi Martii sita, presentibus DD. Stephano Gaillard Bisuntinæ Diocesis, filio quondam Claudii, et Petro Maria Martini clerico Romano, filio quondam Claudii, Romæ residentibus, testibus et rogatis. Jacobus Ant. Redoutey not.

\section{Die 28 septembris I67I}

In mei etc., Joannes Barberi Romanus Sculptor Lignarius, filius quondam Laurentii, Romæ degens, mihi etc. notus, sponte ac omnibus confessus fuit habuisse et recepisse partim in contanti in pluribus et diversis vicibus ab admodum R. Patre M. fr. Petro Lorent ordinis Predicatorum, Procuratore in hac Curia pro canonizatione Sancti Ludovici Bertrandi eiusdem ordinis presente, stipulante et acceptante scuta quadraginta septem cum dimidio monetx Romanx de juliis decem pro quolibet scuto huiusmodi pro solutione sux mercedis, cadulorum, seu doliolorum, cavearum [al margen: panumque] et aliarum rerum similium per eum factorum pro eis presentandis in Basilica S. Petri Prelibato Smo. D. N. D. Clementi Divina Providentia Papæ Xmo. pro canonizatione eiusdem Sancti Ludovici Bertrandi ascendente ad dicta scuta quadraginta septem cum dimidio, de quibus idem Joannes Barberi se benè contentum et satisfactum vocavit et ad ulteriorem cauthelam exceptioni, speique etc. renunciavit, quietavit, etc. per pactum etc. super quibus etc. Actum Romæ in domo solitx habitationis eiusdem Joannes Barberi sita in via Ferratina Regionis Campi Martii, presentibus Petro Petrosini Romano, filio Josephi, et Josepho Tamburlano Lauretanæ Civitatis Anconitanensis Diocesis, filio Caroli, Romæ residentibus, testibus et rogatis. Jacobus Ant. Redoutey not.

\section{Die qua retro}

In mei etc. D. Augustinus Banchieri Romanus Phrygio, filius quondam Francisci, Romæ degens, mihi etc. notus, sponte ac omnibus confessus fuit habuisse et recepisse partim in contanti et partim in unius ordinis directi Ministris et officialibus Banchi Sancti Spiritus de urbe ab admodum R. P. M. fr. Petro Lorent ordinis Predicatorum, Procuratore in hac Curia pro canonizatione S. Ludovici Bertrandi eiusdem ordinis presente, stipulante et acceptante scuta mille sexaginta septem et baiocchos nonaginta septem monetx Romanx de juliis decem pro quolibet scuto huiusmodi pro solutione tertix partis suae mercedis manifacturæ mitræ et armorum Suæ Sanctitatis [al margen: acliorum operum fhrigiorum] per eum factorum pro canonizatione eiusdem S. Ludovici Bertrandi ascendente pro tertia parte ad ipsum R. P. Procuratorem spectante ad dicta scuta centum decem et septem et baiocchos nonaginta octo, de quibus idem D. Augustinus Banchieri se benè contentum et satisfactum vocavit et ad ulteriorem cauthelam exceptioni, speique etc. renunciavit, quietavit, etc. per pactum etc. super quibus etc. Actum Romæ in domo solitæ habitationis eiusdem D. Augustini sita apud Cursores huius Almæ urbis Regionis Pontis seu alterius cuiusvis, presentibus DD. Cinthio Sabatini, filio quondam Vincentis, et Johannes Benedicto Sicarrelli, filio quondam Dominici, ambobus Romanis Rome residentibus testibus et rogatis. Jacobus Ant. Redoutey not.

\section{Die 29 septembris I67I}

In mei etc. R. D. Nicolaus Estamigna Romanus magister Capellæx seu de choro venerabilis ecclesiae Sanctorum Jacobi et Ildephonsi nationis hispanorum de urbe, filius 
quondam Ludovici, Romæ degens, mihi etc. cognitus, sponte ac omnibus confessus fuit habuisse et recepisse partim in contanti et partim in unius ordinis directi ministris et officialibus Banchi S. Spiritus de urbe ab admodum R. P. M. fr. Petro Lorente ordinis Predicatorum, Procuratore in hac Romana Curia pro canonizatione S. Ludovici Bertrandi eiusdem ordinis presente, stipulante et acceptante scuta tercenta sexaginta sex monetx Romanæ de juliis decem pro quolibet scuto huiusmodi pro solutione sue mercedis ei debitx ab eodem R. P. Procuratore pro rata parte spectante ad ipsum tanquam talem Procuratorem S. Ludovici Bertrandi musicx Processionis vexillorum, festorum et octavarum eiusdem S. Ludovici Bertrandi et S. [tachado: M.] Rosæ Limanx celebratarum in ecclesia conventuali S. Marix supra Minervam de urbe eiusdem ordinis Predicatorum ascendente ad dicta scuta tercenta et sexaginta sex, de quibus idem R. D. Nicolaus Estamigna se benè contentum et satisfactum vocavit et ad ulteriorem cauthelam exceptioni, speique etc. renunciavit, quietavit, etc. per pactum etc. super quibus etc. Actum Romæ in sacristia eiusdem venerabilis ecclesiæ SS. Jacobi et Ildephonsi sita in Platea Navonæ Parionis seu alterius Regionis, presentibus perillustribus et admo. RR. DD. Doctor Don Johannes Diaz de Langarica canonico doctorali S. Cathedralis ecclesia Calagurritanensis, filio quondam Johannis, et Don Benedicto Fernandez Bulgarin presbitero Tudensis Diocesis, filio D. Balthazaris, Romæ residentibus testibus et rogatis. Jacobus Ant. Redoutey not.

\section{Die 22 octobris I67I}

In mei etc., D. Johannes Baptista Miralta droguerius Januensis civitatis, filius quondam Antonii, Romæ degens, mihi etc. cognitus, sponte ac omnibus confessus fuit habuisse et recepisse in contanti et partim in unius ordinis directi ministris et officialibus Banchi S. Spiritus de urbe $\mathrm{ab}$ admodum R. P. M. fr. Petro Lorente ordinis Predicatorum, procuratore in hac Romana Curia pro canonizatione S. Ludovici Bertrandi eiusdem ordinis, absente me etc., scuta nongenta quadraginta sex et baiocchos nonaginta octo monetæ Romanx de juliis decem pro quolibet scuto huiusmodi pro solutione tertia partis ceræ que è Venetiis fuit translata [al margen: [...] computum et consignata ab eo dicto R. P. Procururatore] pro canonizatione Sancti Ludovici Bertrandi unacum quatuor aliis Sanctis facta in Basilica Sancti Petri de Urbe et scuta quinquaginta eiusdem monetæ quæ solvit ipse Johannes Baptista Miralta Dno. Alexio Colino pictori in hac Alma urbe et eius domus degenti pro picturis eiusdem Sancti Ludovici Bertrandi traditis Emmo. Dno. Cardinali Portocarrero et Exmo. Dno. Marchioni de Astorga in hac Alma urbe pro Sacra Catholica Maiestate apud prelibatum Sanctisimus D. N. PP. oratori, quxquidem summæ insimul iunctx faciunt totalem summam nongentorum nonaginta sex scutorum et baiochorum nonaginta octo eiusdem monetæ Romanx, de quibus idem D. Johannes Baptista Miralta se benè contentum et satisfactum vocavit et ad ulteriorem cauthelam exceptioni, speique etc. renunciavit, quietavit, etc. per pactum etc. super quibus etc. Actum Romæ in domo solite habitationis eiusdem D. Johannis Baptiste sita in via seu vico Hispanorum nuncupata Regionis S. Salvatoris Cuppellarum seu et presentibus DD. Marco Antonio Peralta, filius D. Johannis Baptistx, Januensis Diocesis, et Antonius de Alefa Mediolanensis Diocesis, filio quondam Francisci, Romæ residentibus testibus et rogatis. Jacobus Ant. Redoutey not.

\section{Dicta die 22 octobris I67I}

In mei etc., D. Camillus del Ponte Romanus aurifex, filius quondam Ranierii, Romæ degens, mihi etc. notus, sponte ac omnibus confessus fuit habuisse et recepisse partim in contanti in partim in unius ordinis directi ministris et officialibus Banchi Sancti Spiritus de urbe ab admodum R. P. M. fr. Petro Lorente ordinis Predicatorum, Procuratore in hac Romana Curia pro canonizatione S. Ludovici Bertrandi eiusdem ordinis absente me etc. scuta tercenta monetx Romanæ de juliis decem pro quolibet scuto huiusmodi pro solutione confectionis simulacrorum eiusdem S. Ludovici Bertrandi traditorum prelibato Smo. D. N. R. et Emmo. D. Cardinali Altieri Patrono nuncupato, ac etiam officiorum per eum confectorum ad dictam summam trecentorum scutorum monetæ Romanæ ascendente de quibus idem D. Camillus del Ponte se benè contentum et satisfactum vocavit et ad ulteriorem cauthelam exceptioni, speique etc. renunciavit, quietavit, etc. per pactum etc. super quibus etc. Actum Romæ in domo solite habitationis eiusdem D. Camilli del Ponte Pine seu alterius Regionis, presentibus DD. Philippo Pasquale Visconti Romano, filio D. Balthasaris, et Josepho Spagna Romano, filius D. Josephi, Romæ residentibus, testibus et rogatis. Jacobus Ant. Redoutey not.

\section{Die 28 octobris I67I}

In mei etc. D. Domenicus Valentinus Droguerius Romanus, filius D. Laurentii, Romæ degens, mihi etc. cognitus, sponte ac omnibus confessus fuit habuisse et recepisse partim in contanti et partim in unius ordinis directi ministris et officialibus Banchi Sancti Spiritus de urbe ab admodum R. Patre Magistro fr. Petro Lorente ordinis Predicatorum, Procuratore in hac Romana Curia pro canonizatione Sancti Ludovici Bertrandi eiusdem ordinis presente, stipulante et acceptante scuta quingenta quadraginta unum et baiochos triginta sex monetx Romanx de juliis decem pro quolibet scuto huiusmodi pro solutione ceræ quam ipse vendidit dicto admodum R. Patri Procuratori attento quod (ut dicitur) non fuit sufficiens illa qux fuit adducta è Venetiis in hunc qui sequitur modum videlicet scuta trecenta sexdecim similia et baiochos triginta sex pro cera quam ei vendidit pro canonizatione celebrata in Basilica S. Petri de urbe Sancti Ludovici Bertrandi et aliorum Sanctorum, et scuta ducenta et viginti quinque etiam similia pro alia cera pariter ab eo vendita pro celebratione festivitatis Sancti Ludovici Bertrandi facta in ecclesia S. M. super Minervam de urbe eiusdem ordinis Predicatorum ascendentes supra recensitæ summæ spectante ad dictum R. P. 
Procuratorem pro tertia parte ad dicta scuta quingenta quadraginta unum et baiochos triginta sex, de quibus idem D. Domenicus Valentini se benè contentum et satisfactum vocavit et ad ulteriorem cauthelam exceptioni, speique etc. renunciavit, quietavit, etc. per pactum etc. super quibus etc. Actum Rom $x$ in apotheca eiusdem D. Domenicus sita in Platea Rotund $x$ Regionis eiusdem seu alterius cuiusvis presentibus DD. Johannes Petro Paolucci Pisaurensis Civitatis, filio quondam Francisci, et Petro Costi Lunensis [et] Sarzanensis Diocesis, filio Dni. Nicolai, Rome residentibus testibus et rogatis. Jacobus Ant. Redoutey not.

\section{Dicta die}

In mei etc. Thomas Ciriaci Romanus, filius quondam Ulissis, Deaurator Romæ degens, mihi etc. notus, tam suo quam Hyeronimi Ciriaci eius fratris germani etiam Deauratoris absentis ab urbe nomine, et tanquam coheredes in bonis et Apotheca, sponte ac omnibus confessus fuit habuisse et recepisse partim in contanti et partim in unius ordinis directi Ministris et officialibus Banchi Sancti Spiritus de urbe ab admodum R. Patre M. fr. Petro Lorente ordinis Predicatorum, Procuratore in hac Romana Curia pro canonizatione Sancti Ludovici Bertrandi eiusdem ordinis presente, stipulante et acceptante scuta quadringenta quinquaginta duo et baiochos quadraginta monetx Romanæ de juliis decem pro quolibet scuto huiusmodi pro solutione sux mercedis in hunc qui sequitur modum ulteriore scuta quadringenta quatuor similia et baiochos nonaginta pro inauratione per eum et dictum fratrem suum facta coronarum tam maiorum quam minorum et scuta quadraginta septem etiam similia et baiochos quinquaginta pro inauratione cavearum, doliolorum et panum oblatorum in Basilica S. Petri de urbe pro canonizatione $S$. Ludovici Bertrandi ascendentes supracensitæ summæ ad dicta scuta quadringenta quinquaginta unum et baiochos quadraginta de quibus idem Thomas Ciriaci tam suo quam dicti eius fratris germani nomine se benè contentum et satisfactum vocavit et ad ulteriorem cauthelam exceptioni, speique etc. renunciavit, quietavit, etc. per pactum etc. super quibus etc. Actum Romæ in apotheca eiusdem Thom $x$ sita prope ecclesiam conventualem Patrum ordinis S. Augustini Regionis Parionis seu alterius cuiusvis presentibus DD. Carolo Ferri Romano, filio quondam Angeli, et Roccho Ranucci Romano, filio quondam Angeli, Romæ residentibus testibus et rogatis. Jacobus Ant. Redoutey not.

\section{Die 29 octobris $167 \mathrm{I}$}

In mei etc. Franciscus Columbus Romanus imaginum et effigierum impressor, filius quondam Horatii Romæ, mihi etc. notus, sponte ac omnibus confessus fuit habuisse et recepisse in contanti in pluribus et diversis vicibus ab admodum R. P. M. fr. Petro Lorente ordinis Predicatorum, Procuratore in hac Romana Curia pro canonizatione S. Ludovici Bertrandi presente, stipulante et acceptante scuta sexaginta monetx Romanæ de juliis decem pro quolibet scuto huiusmodi pro solutione sux mercedis impressionis variarum et plurium imaginum ac effigierum S. Ludovici Bertrandi quæ inservierunt pro canonizatione eiusdem et pro eis distribuendis in illius festivitate celebrata in ecclesia conventuali S. Mariæ supra Minervam de urbe eiusdem ordinis ascendentes ad dicta scuta sexaginta de quibus idem Franciscus Columbus se benè contentum et satisfactum vocavit et ad ulteriorem cauthelam exceptioni, speique etc. renunciavit, quietavit, etc. per pactum etc. super quibus etc. Actum Romæ in apotheca eiusdem Francisci sita in conspectu ecclesiæ Sancti Ignatii Societatis Iesu de urbe presentibus DD. Stephano Gaillard Bisuntinæ Diocesis, filio quondam Claudii, et Petro Maria Martin clerico romano, filio quondam Claudii, Romæ residentibus testibus et rogatis. Jacobus Ant. Redoutey not.

\section{Die qua retro}

In mei etc. D. Nicolaus Angelus Tinazi [al margen: librorum impressor] Sulmonensis Diocesis, filius quondam Simonis, Romæ degens, mihi etc. cognitus sponte ac omnibus confessus fuit habuisse et recepisse in contanti in pluribus et diversis vicibus ab admodum R. P. M. fr. Petro Lorente ordinis Predicatorum, Procuratore in hac Romana Curia pro canonizatione S. Ludovici Bertrandi presente, stipulante et acceptante scuta trecenta monetæ Romanx de juliis decem pro quolibet scuto huiusmodi pro solutione suæ mercedis impressionis per eum facte vitæ compendiorum et orationum S. Ludovici Bertrandi ascendentes ad dicta scuta trecenta de quibus idem D. Nicolaus Angelus Tinazi se benè contentum et satisfactum vocavit et ad ulteriorem cauthelam exceptioni, speique etc. renunciavit, quietavit, etc. per pactum etc. super quibus etc. Actum Romæ in apotheca eiusdem D. Nicolai Angeli sita in conspectu Collegii Romani de urbe presentibus DD. Stephano Stephano Colum Bisuntinæ Diocesis, filio quondam Petri, et Petro Barbet clerico Vicensis Diocesis, filio quondam Petri, Romæ residentibus testibus et rogatis. Jacobus Ant. Redoutey not. 


\section{Apéndice documental 2}

Relatione delle cerimonie E apparato fatto nella Basilica di S. Pietro nella canonizatione de'cinque santi, cioè di $S$. Gaetano Tieneo, di S. Francesco Borgia, di S. Filippo Benitii, di S. Ludovico Beltrando e di S. Rosa di S. Maria, fatta dalla Santità di N. S. PP. Clemente X, Giacomo Dragondelli, I67 I (ASR, Fondo Cartari Febei, vol. 83, f. 62 s.).

Apparato fatto dentro e fuori della Basilica di S. Pietro. L'Apparato che siamo per descrivere fu nobilissimo, e si vago e rico, che appena può giugnerai l'immaginatione. Richiederebbe un volumen se si dovesse descrivere ogni cosa con tutto che grande, con tutto ciò c'ingegneremo di darne qualche saggio, accioche $\mathrm{da}$ quello che legge conghietturi il Lettore ciochè non legge.

La facciata che riguarda la Piazza era adornata di cinque gran quadri, ne'quali erano al vivo dipinte le immagini de'cinque Santi. E né luoghi opportuni vi erano le armi della Santità di N. Signore, delle Maestà Cesarea, e Cattolica. Della Serenissima Republica di Venetia, del Serenissimo Gran Duca di Toscana, delle Città di Valenza, e di Lima, e di tutte quelle Religione delle quali i Santi canonizati sono stati professori.

Il portico era ricamente addobbato di que' panni d'Arazzo d'inestimabile valore perche furono disegnati da quei pittori, che non hanno pari al mondo, cioè da Michel'Angelo Buonaruoti e Raffaelle d'Urbino, eroi della pittura, o pittori divini. Da alto pendevano cartelloni ben disegnati colle Iscritioni et Elogii, inseritivi i Medaglioni, che facevano vaghissimo prospetto. $\mathrm{Da}$ un de' lati del portico vi era eretta una mensa, sopra della quale erano distesi i paramenti di N. Signore, il quale di quel luogo compiacque di servirsi per stanza de'paramenti.

La Chiesa per di dentro rassembrava un paradiso, sì era maestosamente e divotamente abbellita. Dal cornicione alle basi de'pilastri pendeva un parato di Damasco Cremesino, trinato con larghe trine d'oro, e sopra il cornicione vi era della medesima materia un fregio con trine a proportione dell'altezza molto più larghe, che cingeva d'ogn'intorno tutto il gran giro della Chiesa, lavoro si grande, e si ricco, che appena chi lo crede, intendo come possa esser fatto, né tanto lavoro di seta et oro, credesi che possa in nessun altro luogo del mondo essere per un solo effecto radunato, Molte migliaia di candele di cera accesa erano sopra quell'immenso giro del cornicione collocate, le quali con tutto che fossero di otto libre l'una, era però cosí spesse, e frequenti, che ben si conosceva essere stata accoppiata in quelli a quali apparteneva colla divotione la liberalità. Nelli intercolunni stavano situati Medaglioni di grandezza superante di gran lunga l'ordinaria, la quale tanta era quanta fù necessaria accioche aparissero grandi, da chi dal piano della Chiesa miravali. Erano distinti in ottangoli, et in ciascheduno di essi vi erano dipinti i miracoli de' Santi lavorati dall'eccellente pittore Giovanni Carbone. Sotto il Medaglione si leggeva una inscrittione, e sotto di questa stava appeso un candeliere di bella maniera, che sosteneva dodici candele accese. Le nicchie de' pilastri erano piene quali di statue e quali di vaghe pitture lavorate a chiar'oscuro. Pendevano di sopra la Tribuna nove grandi stendardi, due di S. Gaetano. Uno di S. Francesco Borgia. Due di S. Filippo. Due di S. Ludovico. E due di Santa Rosa.

Era l'Altar maggiore adornato con tutta quella magnificenza alla quale poté estendersi la liberalità, e la divotione degli huomini, che pure tanto poté nell'ornare il rimanente della Chiesa per questa santissima funtione, erano la Croce, i Candelieri, le Statue, et i vasi tutti d'argento, i paliotti erano di ricamo grosso fatti con diligenza, e con intelligenza di disegno, contenevano le imagini di tre santi, cioè di $\mathrm{S}$. Francesco Borgia, di S. Lodovico Bertrando, e di S. Rosa di Lima coll'armi di N. Signor e delle due Città di Valenza, e di Lima.

Dietro all'altare vi era il luogo dove si celebrava la funtione, la Cappella et il Teatro. Nel fondo era inalzato il soglio pontificio. In mezzo era collocata la sedia coperta di broccato, sotto un ricco baldacchino parimente di broccato. A i lati vi erano posti due scabelli, i quali servivano per li SS. Cardd. Diaconi assistenti. Et i gradini così ben disposti, che vi potessero stare i SS. Ambasciadori, e gli altri SS. Nipoti, e Principi del soglio. Et accioche vista sì bella, e sì devota fosse comune a molti. $\mathrm{Da}$ ogni lato v'erano costituiti palchi con gelosie, vagamente dipinti, et indorati, che servivano quasi di fregio al sacro Teatro et accrescevano vaghezza al luogo. Stette dentro ai palchi un numero grandissimo di Principi e Principesse, tanto Romani quanto forastieri concorsi a gara a vedere sì nobil funtione, et a godere de'privilegi spirituali, e che goderono i presenti. Erano finalmente le cornici de'palchi premuti da quadri grandissimi degli Apostoli, e de'cinque Santi che si canonizavano, che terminavano per la loro parte la veduta del sacro Teatro, il quale era per quanto quaggiù è lecito di rappresentare un ritratto del Paradiso, dove fù lodato Iddio ne'suoi Santi, e dove si rappresentarono quell'allegrezze che godono colà su, e che goderanno nelle perpetue eternità. 
1. T. Ferrer Valls (1986), «Producción municipal, fiestas y comedia de santos: La canonización de San Luis Bertran en Valencia», en J. L. Canet Vallés (coord.), Teatro y prácticas escénicas. II: La Comedia, Londres, Tamesis Books, p. 156-186. No obstante el título -lapsus calami o errata de imprenta-, en realidad hace referencia a la beatificación. También, K. E. Rylance (1999), «Saint Luis Beltrán in Valencian Art and Pageantry", en W. Reinink y J. Stumpel (ed.), Memory E Oblivion: Proceedings of the XXIXth International Congress of the History of Art (Amsterdam, 1996), Dordrecht, p. 685-690.

2. P. Fr. Joseph Favores O. P. (1671), Sumario de la vida del segundo apóstol valenciano, el glorioso Padre San Luis Bertrán, canonizado solemnemente por nuestro Santíssimo Padre Clemente $X$ a 12 de Abril este Año de 1671, Valencia, Geronimo Vilagrasa. Hay traducción latina, impresa en Roma el mismo año por Nicolò Angelo Tinassi, a veces atribuida a fray Giacomo Ricci O. P. La primera biografía del dominico es la del $\mathrm{P}$. Fr. Vicente Justiniano Antist O. P. (1582), Verdadera relación de la vida y muerte de Padre Fray Luis Bertrán, Valencia, Vda. de Huete. Tuvo numerosas reimpresiones y alguna traducción: Zaragoza, 1583; Pamplona, 1583; Barcelona, 1583; Génova, 1583 (en italiano); Sevilla, 1585; Valencia, 1593; Zaragoza, 1663, y Valencia, 1884. La edición valenciana de 1584 contiene unas adiciones redactadas por fray Luis Martínez O. P., y el mismo año se publicaron en Valencia los Testimonios de la santidad y bienaventuranza del padre Fr. Luys Bertran, del P. Fr. Nicolás Factor O. F. M. La segunda biografía, coincidiendo con la beatificación, la debemos al P. Fr. Baltasar Roca O. P. (1608), Historia verdadera de la vida y milagros del bienaventurado Padre Luis Bertran, hijo de la Ciudad y Convento de Predicadores de Valencia; y su Beatificación por nuestro Santo Padre Paulo Papa $V$, Valencia, Juan C. Gariiz. Al año siguiente apareció la del P. Fr. Cosme Morrelles O. P. (1609), Compendiosa Relatio Vitae Eximiae Sanctitatis Viri Fr. Ludovici Bertrandi Sacri ordinis Praedicatorum Anno 1608 a SS. Domino Paulo divina providentia Papa huius nominis V. Beatificati, cum rescripto Beatificationis. Summarie collecta, Colonia, Arnoldi Kempensis. De la misma época debe ser una biografía inédita redactada por tres auditores de la Rota: G. CAvalieri, A. Manzanedo de QuiÑones y
G. B. Coccini, De sanctitate vitae et miraculis B. Ludovici Bertrandi Ordinis Praedicatorum, Biblioteca Casanatense de Roma, Ms. 951. Las dos siguientes biografías tienen un interés añadido, porque incluyen documentación de la causa pía, por entonces paralizada: P. Fr. Bartolomeo Avignone O. P. [Bartolomé Aviñón] (1623), Vita, Virtù e Miracoli del Beato Luigi Bertrando del Ordine de Predicatori, traducida del original castellano por G. C. Cavalier Bottifango, Roma, Alfonso Ciacconio, y P. Fr. Vicente SABORIT O. P. (1651), Historia de la vida, virtudes y milagros del Beato Luis Bertran, de la Orden de Predicadores, Valencia, Bernardo Nogués. Ambos autores habían sido procuradores de la causa en Roma. A raíz de la canonización, se publicó una biografía completa dedicada al papa: Odoardo Cellerno [Leandro Colloredo] (1671), Vita di San Luigi Bertrando Dell'Ordine de' Predicatori raccolta da processi fatti per la sua canonizatione, Roma, Nicol'Angelo Tinassi. Un relato más sintético es el anónimo Breve Ristretto della meravigliosa vita, virtù e miracoli del Santo Luigi Bertrando [...], Viena, Matteo Cosmerovio, s. d. [1671]. O bien el que se incluye en Carlo ToMASI (1671), Immagini de'Cinque Santi Clementini, Gaetano, Francesco, Filippo, Luigi, Rosa, spiegati encomiasticamente allà Santità di N. S. Clemente X, Pontefice Massimo, Ignatio de Lazari, Roma. Y, todavía, un anónimo Brevissimum Compendium Vitae, Virtutum E Miraculorum, necnon actorum in causa Beatificationis \& Canonizationis Beatorum Caietani Thienaei Francisci Borgiae, Philippi Benitii, Ludovici Bertrandi et Rosae de S. Maria. Roma, Ex Secretaria Congregationis Sac. Rituum, Typ. Rev. Cam. Apost., 1671, p. 13-16. Sin embargo, la biografía que podemo considerar «oficial» — al menos en latín- es la Admiranda Vita, Virtus, Gloria S. Ludovici Bertrandi, Valentini Ordinis Praedicatorum Indiarum Occidentalium Apostoli S. Vincentio Ferrerio Eiusdem Ordinis E Patriae Viro Apostolico et sanguinis cognatione $\mathcal{E}$ pietatis officio vitaeque imitatione conjunctissimi a S. D. N. Clemente $X$ Solemni Canonizationis ritu hoc Anno MDCXXI, die XII. Aprilis ab ortu suo CXLV à felici transitu XC. Sanctorum Catalogo inscripsi. Ex probatissimis Scriptoribus Compendio enarrata... [Augsburgo], Simonis Uzschneider, Augusta Vindel, 1671. Del mismo año, P. Fr. J. B. Feuillet (1671), La vie de $S$. Louis Bertrand de l'Ordre des FF. Prêcheurs, Missionaire Apostolique aux Indes Occidentales, París, An- dré Cramoisy, traducida al latín por P. Fr. Hyacintho CuniberT (1671), Compendium Thaumaturgae Vitae S. Ludovici Bertrandi Ord. Praedicatorum, Indiarum Occidentalium Apostoli, Colonia, Petri Steinbuchel. Prácticamente todas las ediciones citadas se pueden consultar en línea. No creo necesario por ahora citar biografías posteriores. No obstante, entre las modernas, conviene recordar las de A. SÁNCHEz (1953), El Apóstol del Nuevo Reino, San Luis Beltrán, Bogotá, Ed. Kelly; P. Fr. R. Frascisco O. P. (2003), San Ludovico Bertràn: Missionario in Colombia, Patrono dei Maestri dei Novizi, Boloña, Studio Domenicano (ed. en español: Bogotá, 2011), y San Luis Bertrán: Reforma y Contrarreforma española, Valencia, Provincia Dominicana de Aragón, 1973.

3. Seguramente se refiere a Castro, de la región italiana de Apulia, antigua sede episcopal y feudo de Pedro Antonio de Castro, X conde de Lemos y virrey del Perú, la esposa del cual, Ana Francisca de Borja-Centelles, fue una promotora entusiasta de la canonización de Rosa de Lima.

4. El aristócrata murió sin descendencia en 1674 y dejó sus bienes a los Borja, duques de Gandía, lo que desencadenó un enojoso pleito con los Catalá de Valeriola. En todo caso, el P. Favores pone el acento en el protagonismo del noble («a cuyo afecto, devoción y diligencias se deve especialmente la Canonización de nuestro Santo»), una cuestión que el resto de documentación conocida calla.

5. C. Rodrigo Zarzosa (2008), «Solemnes fiestas celebradas en Valencia por las canonizaciones de San Luis Bertrán y San Francisco de Borja en el año 1671», en El culto a los Santos: Cofradias, devoción, fiestas y arte, San Lorenzo de El Escorial, Ediciones Escurialenses, p. 989-1006. Además, V. Mínguez (1993), «Emblemática y cultura caballeresca: Divisas valencianas en la canonización de san Francisco de Borja en 1671", Ars Longa, 4, p. 65-72. Sobre la fiesta barroca en Valencia, en general, véase V. Mínguez, P. González Tornel e I. Rodríguez Moya (2010), La fiesta barroca: El reino de Valencia (1599-1802), Castellón, Universitat Jaume I.

6. Relatione delle feste celebrate in Napoli nel mese d'agosto M.DC. LXXI per la solemne canonizatione di S. Gaetano Tiene Fondatore della Religione de'Cherici Regolari, Roma, Ignatio de Lazari, 1671. 
Ahora bien, el papel protagonista correspondió al virrey Pedro Antonio de Aragón, duque de Segorbe y Cardona, retratado a los pies de Clemente $\mathrm{X}$ en una pintura colocada sobre el portal principal de la iglesia. Se cita la participación del «Signor Marchese Centelles, Luogotenente della Camera» (p. 32), que decoró la fachada de su palacio con ricchi drappi o tapices (p. 34).

\section{T. López de los Ríos (1674),} Auto Glorioso: Festejo sagrado con que el insigne Colegio de la Preclara Arte de Notaría celebró la canonización de el Señor S. Luis Bertran, Valencia, Geronimo Vilagrasa. Conviene recordar que el santo era hijo de un notario valenciano. El texto desarrolla una defensa de la profesión de notario, una biografía del santo y una descripción detallada de la fiesta celebrada en el convento dominico y por las calles de la ciudad en 1671. Está ilustrado con algunos de los emblemas diseñados para la ocasión.

8. Los diputados de la Generalitat Valenciana solicitaban poder gastar 2.000 libras, pero la reina solo aprobó la mitad. En cambio, el Consell de la ciudad aportó 4.000 libras para las fiestas de Luis Bertrán y Francisco de Borja. Las cortes del año 1585 habían aprobado una partida de 16.000 libras en caso de canonización del dominico, pero surgieron muchas dificultades para hacerlas efectivas. Hay documentación sobre este tema en el Arxiu de la Corona d'Aragó (ACA), Consell d’Aragó, leg. 690, núm. 121; leg. 780, núm. 64; leg. 820, núm. 14.

9. ACA, Consell d'Aragó, leg. 820, núm. 14. El 28 de agosto de 1671 se pesaba la imagen de plata y el 1 de septiembre hacían la visura D. Félix Falcó, elegido por los clientes, y Severino Arboleda, en nombre del orfebre. Véase, además, F. de P. Cots Morató (2013), «Piezas de platería de la catedral de Valencia desaparecidas durante la Guerra Civil española», Laboratorio de Arte, 25, p. $143-$ 169. El autor anuncia un trabajo sobre esta pieza en concreto.

10. F. de P. Cots Morató (2005), Los plateros valencianos en la edad moderna (siglos XVI-XIX): Repertorio biográfico, Universitat de València, ad vocem.

11. Es fundamental el artículo pionero de V. CASAle (1979), «La canonizzazione di S. Filippo Benizi e l'opera di Baldi, Berrettoni, Garzi, Rioli, Maratti», Antologia di Belle Arti, 9-12, 113-131. Para la fiesta del octavario romano, Relazione del nobilissimo apparato fatto nella Chiesa di San Marcello in occasione del solenne Ottavario consacrato allà festività della canonizazione di S. Filippo Benizi, Roma, Ignatio de Lazari, 1671. Es muy minucioso - grabados, nombre de artistas, etc.- el relato de la fiesta celebrada en Florencia, escrito por Fr. Prospero Bernardi (1672), Applausi di Firenze per la canonizzazione di S. Filippo Benizi, Propagatore dell'Ordine de'Servi di Maria Vergine, Florencia, Stamperia della Stella. Para una visión general del tema, V. Casale (1997), «Gloria ai beati e ai santi: L'arte della canonizzazioni», en M. Fagiolo DELl'Arco (a cargo de), La festa a Roma dal Rinascimento al 1870, Turín, Allemandi, vol. 1, p. 124141; V. Casale (2011), L'arte per le canonizzazioni, l'attività artistica intorno alle canonizzazioni e alle beatificazioni del Seicento, Turín, Allemandi, y V. Casale (2012), «La basilica di S. Pietro nelle cerimonie di beatificazione e di canonizzazioni del Seicento», en G. Morello (a cargo de), La basilica di San Pietro, fortuna e immagine, Roma, Gangemi, p. 445-454.

\section{J. Curzietti (2011), Giovan} Battista Gaulli: La decorazione della chiesa del SS. Nome di Gesù, Roma, Gangemi, en particular el primer capítulo, dedicado a Lazzaro Baldi y la canonización del gandiense. Hay una relación anónima: Breve racconto di quanto è seguito in Roma per la celebrità della Canonizatione di S. Francesco Borgia Terzo Generale della Compagnia di Giesù, Roma, impr. Varese, 1671. Para las fiestas que se le dedicaron en España, véase M. Bernal (2012), «Aspectos teatrales en las fiestas de canonización y beatificación de Francisco de Borja», en S. la PARra; M. Toldrà (a cargo de), Francesc de Borja (15101572), bome del Renaixement, sant del Barroc (Actes del Simposi Internacional, Gandia-València, 2010), Gandía, p. 423-438.

13. Aunque Vittorio Casale les dedica alguna atención, las celebraciones teatinas merecen un estudio particularizado. Como era previsible, se conservan relaciones de las numerosas fiestas que se le dedicaron al menos en Vicenza, Milán, Venecia, Módena, Bérgamo, Verona, Cremona, Ferrara y Messina, además de la de Nápoles ya citada. Durante la novena solemnizada en Sant'Andrea della Valle, el interior estaba decorado por un árbol simulado de proporciones gigantescas, engalanado con una estatua de san Pedro en la base y medallones de santos en las ramas, incluido Cayetano. Aparece reproducido y glosado en Josepho SiLos C. R. (1671), Plausus in solemni consecratione D. Caietani Thienaei Clericorum Regularium Institutoris, Roma, Ignatii de Lazaris.

14. Archivio Storico Capitolino di Roma (ASCR), Archivio Generale Urbano, Sez. 1, vol. 632, not. J. A. Redoutey. Este individuo, JacquesAntoine Redoutey, notario público apostólico, era oriundo de Besanzón. Residía en la vía Frattina, en la parroquia de S. Lorenzo in $\mathrm{Lu}-$ cina. Sus principales clientes eran franceses, borgoñones, flamencos y españoles. En 1674 era secretario de la cofradía de Saint-Claude, propia de los franco-condeses. Fue también notario de la embajada española y gozó de la confianza de Gaspar de Haro, marqués del Carpio. En el ASCR se conservan una docena de volúmenes protocolizados por él, fechados entre $1667 \mathrm{y}$ 1683. Hace ya tiempo que localicé esta documentación gracias a una beca del Ministerio de Educación para estancias de profesores e investigadores séniores en centros extranjeros de enseñanza superior e investigación (2010-2011), en particular en La Sapienza de Roma, donde fui amablemente acogido por Sergio Rossi. Agradezco asimismo la generosidad de los colegas franceses del grupo PICTOR (Michel Hochmann, Guy-Michel Leproux, Julien Lugand y Audrey Nassieu-Maupas), que en 2018 me han facilitado una estancia en l’École Française de Roma, con el objetivo de revisar y completar la documentación.

15. El valenciano P. Pedro Lorente ingresó en la orden de predicadores en 1627. Maestro en teología, fue prior del convento de Valencia, donde murió en 1679. Consta además como predicador de Clemente IX. A veces se le ha atribuido una biografía del santo, cuando en realidad es obra de L. Colloredo (cfr. supra n. 2). Véase P. Fr. J. RoDRÍGUEZ O. S. T. (1747), Biblioteca Valentina, Valencia, J. T. Lucas, p. 488, y V. Ximeno (1747), Escritores del Reyno de Valencia, Valencia, J. E. Dolz, I, p. 85.

16. El nombramiento fue protocolizado en Valencia por el notario Vicent Valls. Se conserva una copia en ASCR, Archivio Generale Urbano, Sez. 1, vol. 632, not. J. A. Redoutey; 1671, 3 de octubre. Acto seguido, Lorente nombraba procuradores a dos mercaderes residentes en Nápoles, Prospero Parisani y Carlo Giani, con el mandato de cobrar del virrey 
Pedro Antonio de Aragón 2.000 ducados napolitanos que la reina había concedido el 25 de abril de 1668 para sufragar los gastos de canonización.

17. La bibliografía es abundante, pero para la cuestión del ceremonial es aún de gran interés $\mathrm{G}$. Moroni (1841), Dizionario di erudizione storico-ecclesiastica di $S$. Pietro sino ai nostri giorni, Venecia, Tip. Emiliana, VII, p. 280-320.

18. En este sentido se ha observado recientemente que estas relaciones pueden ser consideradas un segmento estructurado del aparato global de canonización, de una misma categoría, tanto por el concepto como por la finalidad. Véase B. Majorana (2013), "CComparendo infine la Festa”. La canonizzazione di Tomás de Villanueva: Apparati da Roma a Bordeaux (1658-1659)», en P. A. Iturbe SAÍz y R. Tollo (coord.), Santo Tomás de Villanueva: Culto, historia y arte. I. Estudios y láminas, San Lorenzo de El Escorial-Tolentino, p. 101-124.

\section{Relatione Delle Cerimonie,} et Apparato Fatto nella Basilica di San Pietro nella Canonizatione de'Cinque Santi, cioè di S. Gaetano Tieneo, di S. Francesco Borgia, di S. Filippo Benitii, di S. Ludovico Beltrando, e di S. Rosa di S. Maria [...], Roma, Giacomo Dragondelli, 1671. Se ha consultado el ejemplar del Archivio di Stato de Roma (ASR), Fondo Cartari Febei, busta 83, f. 62 s. Hay también edición milanesa (Milán, Beltramino, 1671). Menos conocida es la traducción castellana, sintética: Relación de las ceremonias que se han becho en la Iglesia de S. Pedro, en la Canoniçación de los cinco Santos, que son: San Cayetano Tiene, San Francisco Borja, San Felipe Benicio, San Luys Beltran, Santa Rosa de Santa María. Hecha por nuestro Muy Santo Padre Clemente $X$, Madrid, Julián de Paredes, 1671.

20. Sobre todo, T. Weddigen (2017), «Materiality and Idolatry: Roman Imaginations of Saint Rose of Lima», en C. GöTTLER y M. M. Mochizuki (ed.), The Nomadic Object: The Challenge of World for Early Modern Religious Art, Leiden-Boston, Brill, p. 103-146. Además, entre otros, T. HAMPE MARTínez (1996), «El proceso de canonización de Santa Rosa (nuevas luces sobre la identidad criolla en el Perú colonial)», Hispania Sacra, 48 (98), p. 719-740; R. Mújica Pinilla (2001), Rosa limensis: Mística, política e iconografía en torno a la patrona de América, Lima, IFEA-FCE-BCRP, y M Zugasti (2013), «Santa Rosa de Lima, una santa del pueblo con sus fiestas y comedias para el pueblo», en J. M. Díez Borque et al. (ed.), Teatro español de los Siglos de Oro: Dramaturgos, textos, escenarios, fiestas, Madrid, Visor, p. 117-151.

21. ACA, Consell d'Aragó, leg. 902, núm. 130 (1655) y leg. 908, núm. 8 (1660).

22. Cfr. supra n. 2. El P. Saborit, natural de Vilafermosa, fue regente de estudios y prior del convento de Valencia, vicario general de la provincia de Aragón y juez sinodal del arzobispado de Valencia. Murió en 1670.

23. Parece ser que A. González de Acuña (Lima, 1623 - Trujillo, Venezuela, 1682) era criollo, hijo de militar. Fue catedrático de teología, regente de estudios en el convento de Lima y definidor de la provincia de Perú antes de pasar a Roma, donde fue nombrado visitador de Nápoles y provincial de Tierra Santa, además de asistente personal del P. general G. B. de Marinis. Promovido a la diócesis de Caracas en 1670, tomó posesión mediante un procurador $\mathrm{y}$, personalmente, tres años más tarde. Véase, entre otros, R. URDANETA (2001), «El muy Ilustre Fray Antonio González de Acuña, XIV ${ }^{\circ}$ Obispo de Venezuela», Boletín de la Academia Nacional de la Historia (Caracas), 84 (336), p. 125-154.

24. J. M. de Garganta O. P. (1981), «Un capítol gironí d'història espiritual», Annals de l'Institut d'Estudis Gironins, XXVII, p. 133-144. Véase, además, San Luis Bertran. Reforma..., 1973 (cfr. supra n. 2). El grabado citado se basa en un original de Joan Baptista Pi. Cuando era arzobispo de Valencia, Rocabertí también hizo publicar los sermones del santo acompañados de una sucinta biografía, todo en dos volúmenes (Valencia, 1688-1690).

25. Sin embargo, los últimos pontífices no habían sido demasiado generosos con la orden. Dejando de lado a Rosa de Lima, únicamente se había declarado el culto inmemorial -es decir, la beatificación equipolente- de las terciarias dominicas Coloma de Rieti y Margarita de Saboya.

26. Véase, por ejemplo, F. GraZIANo (2002), "Santa Rosa de Lima y la política de la canonización», Revista Andina, 34, p. 9-45, y F. Quílez García (2012), «Cerca del cielo: La creación de los santos y su imagen en la América hispana», Semata: Ciencias Sociais e Humanidades, 24, p. 89-109. O bien, entre otras publicaciones del autor, A. Rubial García (2009), «La evangelización novohispana (15231750)», en F. Armas (ed.), La invención del catolicismo en América: Los procesos de evangelización, siglos XVI-XVIII, Lima, Universidad de San Marcos, p. 45-67. Y, más genéricamente, M. GoTOR (2007), «Le canonizzazioni dei santi spagnoli nella Roma barocca», en C. J. Hernando Sánchez (ed.), Roma y España, un crisol de la cultura europea en la edad moderna.

Madrid, Seacex, II, p. 621-639; A. Agresti (2014), «Le canonizzazioni come impulso alla produzione artistica nella Spagna del xvir secolo», en A. Anselmi (ed.), I rapporti tra Roma e Madrid nei secoli XVI e XVII: Arte diplomazia e politica, Roma, Gangemi, p. 557-585.

27. Por su interés objetivo, porque en la versión castellana de la Relación este capítulo desaparece y porque hasta ahora solo se han transcrito breves fragmentos, el texto completo se reproduce ahora, en el apéndice 2.

28. L. Beaven (2008), «Cardinal Camillo Massimo as Art Agent of the Altieri», en J. Burke y M. Bury (ed.) (2008), Art and Identity in Early Modern Rome, Oxford, Routledge, cap. 9 (en línea).

29. S. L. Forte O. P. (1963), «Il domenicano Giuseppe Paglia architetto siciliano a Roma (16161683)», Archivum Fratrum Praedicatorum, XXXIII, p. 281-394. Paglia rivalizó con Bernini en varias ocasiones y, en particular, para la traza del Elefantino de la Minerva; en cambio, recibió influencia notable de Borromini, a quien substituyó en la dirección de las obras del Colegio de Propaganda Fide. Véase M. Tabarrini (2009), «Francesco Fontana, Giuseppe Paglia e G.

B. Contini architetti di Propaganda Fide: Il completamento del Collegio Urbano e un progetto di Abraham Paris per il Collegio Illirico di Fermo", en M. Fagiolo y G. BoNACCORSO (a cargo de), Studi sul Fontana: Una dinastia di architetti ticinesi a Roma tra Manierismo e Barocco, Roma, Gangemi, p. 261284; P. GonzÁlez TORnel (2015), "La iglesia de los santos Ildefonso y Tomás de Villanueva en Roma: Un monumento barroco a la Pietas Hispanica», Archivo Español de Arte, LXXXVIII, 349, p. 69-84.

30. M. Fagiolo y S. Roberto (1990), «Un'opera berniniana per 
Clemente IX: La cappella di S. Domenico nel convento di S. Sabina a Roma», Palladio, 5, p. 63-90, y S. Roberto (2004), Gianlorenzo Bernini e Clemente IX Rospigliosi: Arte e architettura a Roma e in Toscana nel Seicento, Roma, Gangemi.

\section{A. Russo (2016), «Gianlo-} renzo Bernini, Mattia De Rossi e un progetto per la cappella di San Domenico nel convento di Santa Sabina all'Aventino", ArcHistoR, 6, p. 22-35.

32. ASCR, Archivio Generale Urbano, Sez. 1, vol. 631, not. J. A. Redoutey; 1670, 3 de marzo.

33. Ibídem; 1671, 15 de octubre. En el mismo volumen se conservan otros protocolos relacionados con González de Acuña: poder a favor del capitán D. Juan de Ibarra Beitía, residente en Madrid (1670, 15 de febrero); nombramiento de procurador substituto del convento de San Pedro Mártir de Quito (1671, 28 de febrero); nombramiento de procurador a favor del P. Lorenzo Muñoz O. P. para la toma de posesión del obispado de Caracas (1671, 23 de abril); acta de profesión de fe, aceptación de la dignidad episcopal y reconocimiento de firma y sello (1671, 5 de mayo); remesa de reliquias procedentes de Colonia hacia Lima $(1671,21$ de septiembre); ápoca a D. Diego de Valladolid, presbítero, por 2.000 pesos de a ocho reales procedentes del colegio de Santo Tomás de Lima (1671, 17 de octubre). Algunos documentos se refieren a préstamos y legados destinados a sufragar la canonización de santa Rosa de Lima (1670, 25 de agosto; 1670, 19 de noviembre; 1671, 14 de marzo; 1671, 23 de abril). El 4 de enero de 1668, ya en Roma, González de Acuña actuaba como testamentario de D. José de Vides, devoto de los dominicos: ASCR, Archivio Generale Urbano, Sez. 1, vol. 204, not. Juan Caballero. La financiación de la canonización de Rosa de Lima es un tema espinoso: E. Callado Estela (2009), «Una santa, dos maestros y una estafa: Sombras en torno a la canonización de Rosa de Lima", Hispania Sacra, LXI (123), p. 147-157.

34. Una inscripción en el muro de la derecha es explícita: D.O.M. IN HONOREM S. ROSAE VIRGINIS LIMEN. [...] HOC SACELLUM F. ANTONIUS GONZALEZ EPISCOPUS CARACEN. ORD. PRAED. DICTAE VIRGINIS PATRIOTA ET APOTHEÔSIS PROCURATOR EXSTRUXIT, ORNAVIT, DICAVIT. MDCLXXI. Enfrente, otra inscripción recuerda el patrocinio asumido por los Colonna di Paliano. Véase V. ForCella (1869), Iscrizioni delle chiese e d'altri edificii di Roma dal secolo XI fino ai giorni nostri, Roma, Tip. Ludovico Cecchini, I, p. 502, núm. 1934, año 1672.

\section{G. Celio (1638), Memoria} fatta dal Signor Gaspare Celio dell'babito di Christ: Delli nomi dell'Artefici delle Pitture che sono in alcune Chiese, Facciate e Palazzi di Roma, Nápoles, Scipione Bonino, p. 64. En uno de los muros laterales se conserva el monumento funerario de Francesco Caffarelli, padre del cardenal Borghese; véase M. Hill (1998), Cardinal Scipione Borghese's Patronage of Ecclesiastical Architecture, 1605-33, PhD Dissertation, University of Sydney, p. 105-107. El altar fue consagrado por el papa en 1726, como se reseña en el Chracas: Diario ordinario di Roma, I (1718-1736); 1726, 12 de octubre. El escudo de los Caffarelli aparece en la clave de bóveda, de época del cardenal Borghese, y en la reja, quizá del año 1825 , coincidiendo con un jubileo.

36. C. Pietrangeli (a cargo de) (1980), Guide rionali di Roma: Rione IX-Pigna. Parte I, Roma, Fratelli Palombi, p. 60.

37. Angelo Martino Listi (1671), Relatione del sontuosissimo apparato fatto nella Chiesa di S. Maria sopra Minerva in occasione di solennizarsi la festa della Canonizatione di S. Ludovico Beltrando e S. Rosa di S. Maria, Roma, Nicol'Angelo Tinassi, p. 8-9. La publicación està dedicada al P. Rocabertí. Se ha consultado el ejemplar del ASR, Fondo Cartari Febei, vol. 83 , f. 144-150.

38. En la misma iglesia, santo Domingo tiene capilla propia en el extremo del transepto izquierdo. Según F. Titi, estaba inacabada en 1674. Fue totalmente remodelada en 1725 por Benedicto XIII como capilla funeraria.

39. Poco antes Gaulli había pintado el retrato del cardenal Paluzzo Altieri (Karlsruhe, Staatliche Kunsthalle). Por entonces estaba finalizando una de sus obras más ambiciosas, las Virtudes de las pechinas de la cúpula de Sant'Agnese in Agone, una obra determinante para obtener el encargo de la decoración de la bóveda del Gesù, sin duda el tour-de-force más espectacular - y correggesco- del pintor.

\section{0. [J. Gomendradi], Festivas} demonstraciones que consagró a la solemne Beatificación de el Gran Pontífice Pio Quinto el Reverendissimo P. Fr. Iuan Thomas de Rocaberti, Roma, Nicolás Ángel Tinas[si], 1672. El nombre del autor, que también redactó una genealogía de la casa Rocabertí, no aparece en la portada, sino en la primera página interior. La asistencia al octavario fue masiva. Destaca la presencia del papa con su corte, una treintena de cardenales, la reina Cristina de Suecia en dos ocasiones, etc.

41. Algunos detalles sobre los cuadros que adornaban la fachada se encuentran en P. A. Maffei (1712), Vita di S. Pio Quinto Sommo Pontifice dell'Ordine de'Predicatori, Roma, Francesco Gonzaga, p. 635-645. Giovanni Peruzzini era el autor de la pintura más importante: Pio V libra al embajador español el breve de nombramiento como general de la Armada a favor de Juan de Austria, una obra que la crítica especializada no cita. En cuanto a la fiesta celebrada en $\mathrm{S}$. María la Mayor, ibídem, p. 645-647.

42. F. Tiтi (1674), Studi di pittura, scoltura et architettura nelle Chiese di Roma, Roma, Mancini, p. 168. Es evidente que la pala d'altare del Cavalier d'Arpino dedicada a santo Domingo había sido substituida muy pronto por un cuadro de la Crucifixión de Cristo de G. Siciolante da Sermoneta, a menos que Titi se equivoque.

43. M. V. Brugnoli (1949), "Contributi a Giovan Battista Gaulli», Bollettino d'Arte, XXXIV (3), p. 225-239.

44. F. Petrucci (2009), Baciccio: Giovan Battista Gaulli. 1639-1709, Roma, Ugo Bozzi (con bibliografía exhaustiva), p. 519-520.

45. En pintura son significativas las imágenes de Sarinyena. El santo aparece solo y aparenta una vera effigies en las versiones del Museo Goya de Zaragoza y del Colegio del Patriarca de Valencia o acompañado de san Jacinto en la del Museo de Bellas Artes de Valencia.

46. E. MÂLE (1932), El arte de la Contrarreforma, Madrid, Encuentro, 2001, p. 96.

\section{V. SAborit (1651), Historia} de la vida..., op. cit., p. 233. Sobre la iconografía del santo, poco estudiada y hasta ahora centrada sobre todo en los orígenes, véase R. Rodríguez Culebras (1981), «Vida, actividad y milagros de San Luis Bertrán: Escenas a que da lugar el arte», Cuadernos San 
Luis Bertrán, Valencia, p. 499-504; R. Rodríguez Culebras (1983), "Apuntes para una iconografía de San Luis Bertrán», Corrientes espirituales en la Valencia del siglo XVI, 1550-1600, Actas del II Simposio de Teología Histórica, Valencia, p. 367-379; L. ViVES-FERRÁNDIZ SÁNCHEZ (2005-2006), «El milagro del árbol surgido entre san Luis Bertrán y un atacante. Complejidad de una obra de José Orient», Ars Longa, 14-15, p. 175-179; L. Vives-FerRándiz SánCHEZ (2008), «La construcción de la Imagen de San Luis Bertrán en Valencia», en C. Chaparro et al. (ed.), Paisajes emblemáticos: La construcción de la imagen simbólica en Europa y América, Mérida, Ed. Regional de Extremadura, II, p. 715-731, e I. Puig Sanchis y B. Franco Llopis (2014), «Juan de Sariñena y Luis Beltrán, dos iconos de la espiritualidad en el arte valenciano: Apreciaciones a propósito del lienzo conservado en el Museo Ibercaja-Camón Aznar de Zaragoza», Archivo de Arte Valenciano, XCV, p. 31-46.

48. Por citar un solo ejemplo, el jesuita Francisco Javier había sido canonizado en 1622 y a partir de 1672 dispuso de capilla propia en la iglesia del Gesù.

49. El proceso, con las bulas de beatificación y canonización, está publicado en Acta Sanctorum octobris, Bruselas, 1786, V (10-11 de octubre), p. 292-488. Para la traducción al castellano, A. Robles y M. Llop (ed.) (1983), Procesos informativos de la beatificación y canonización de San Luis Bertrán, Valencia, Provincia Dominicana de Aragón.

50. Oriundo de la diócesis de Ascoli, fue canónigo de Santa Anastasia, donde está enterrado, y de Santa Maria in Trastevere, además de maestro de ceremonias pontificias (1681-1696).

51. D. Cappelli (1665), Contextus Actorum omnium in Beatificatione et Canonizatione S. Francisci de Sales Episcopi Genevensis, Roma, Iacobi Dragondelli. Por citar solo algunos ejemplos: el theatrum magnum de madera costó 2.310 escudos; la cera, 2.622 escudos; los tres estandartes con la efigie del santo, 590 escudos; cuatro pinturas ovaladas y catorce cuadradas con escenas de milagros, 423 escudos; los retratos destinados al papa y a otras autoridades, 1.160 escudos. El capítulo más oneroso era el del ajuar litúrgico, sobre todo la indumentaria: la mitra pontificia, 634 escudos; el tejido de lama de plata,
992 escudos, y la manufactura de los bordadores, 2.393 escudos. En resumen, por el material y la confección del ajuar (sacra supellectili), casi 4.629 escudos.

\section{D. Cappelli (1669), Acta ca-} nonizationis S. Petri de Alcantara et S. Mariae Magdalenae de Pazzis, Roma, Fabii de Falco. Así, el teatro costó 1.674 escudos; la cera, 4.438 escudos; el ajuar litúrgico, 5.027 escudos, incluida la mitra papal, de 255 escudos; el trabajo de los bordadores, 3.985 escudos, etc. En sedas y brocados se gastaron más de 25.000 escudos. En cambio, la pintura resultaba relativamente más barata: cuatro estandartes, 1.418 escudos; los retratos de los santos destinados a las numerosas dignidades, 3.663 escudos, y las pinturas narrativas (dos octogonales, veinte cuadradas, tres ovaladas), con los correspondientes escudos, emblemas e inscripciones, 1.017 escudos. La publicación tiene un interés añadido, ya que recoge las deliberaciones de la Congregación de Ritos y del Consistorio Secreto, además de la habitual relación de la fiesta, ilustrada con un grabado.

53. El verdadero alcance de este dispendio solo se comprende si se tienen otras referencias para el mismo siglo Xvir: el salario mensual de un obrero especializado, unos 3 escudos, y el salario diario de un maestro de obras, medio escudo; el gasto anual en pan de una familia de cuatro miembros, unos 12 escudos; etc.

54. G. Moroni (1841), Dizionario di erudizione..., op. cit., VII, p. 315.

\section{Ibídem, VII, p. 316-317.}

56. B. Majorana (2008), «Feste a Milano per la canonizzazione di santi spagnoli (secolo XVII)», en M. C. de Carlos Varona et al. (eds.), La imagen religiosa en la Monarquía hispánica: Usos y espacios, Madrid, Casa de Velázquez, p. 103-117, n. 50. Véase, asimismo, M. Boiteux (2004), «Le rituel romain de canonisation et ses représentations à l'époque moderne", en G. Klaniczay (ed.), Procès de canonisation au Moyen Âge: Aspects juridiques et religieux, École Française de Rome, p. 327-355.

57. Agustín de Hipona, Contra Faustum Manichaeum, XX, 21.

58. Relatione delle cerimonie et apparato della Basilica di S. Pietro nella beatificatione del glorioso Martire Pietro d'Arbues, Roma, G. Dragondelli, 1664. La decoración interior era suntuosa gracias a la iluminación, los damascos y los brocados, pero con menos figuración que en una canonización. Sobre el altar dedicado al beato, cubierto con baldaquín, había una pintura de Giacinto Brandi. Como era costumbre, en la fachada principal colgaba otro retrato del protagonista.

59. V. Casale (1979), «La canonizzazione di S. Filippo Benizi...», op. cit.

60. V. Casale (1983-1984), «Alcune precisazioni sui disegni di Lazzaro Baldi», Prospettiva, 33 (36), p. 262-275. El artículo es una reseña implícita a A. Pampalone (a cargo de) (1979), Disegni di Lazzaro Baldi nelle collezioni del Gabinetto Nazionale delle Stampe, Roma, catálogo de exposición.

61. Para una sintética reseña de la vida y obra del pintor, véase C. SESTIERI (1994), Repertorio della pittura romana della fine del Seicento e del Settecento, 3 vols., Turín, Umberto Allemandi, I, p. 18-20. Además, M. G. Bernardini (1997), «Lazzaro Baldi», en A. lo Bianco y L. Barroero (a cargo de), Pietro da Cortona 1597-1669, catálogo de exposición (Roma, 1997-1998), Milán, Electa, p. 213-222.

62. Las equivalencias monetarias en Roma eran 1 escudo = 10 julios (julii) $=100$ bayocos (baiocchi) .

63. F. Baldinucci (1728), Notizie dei Professori del Disegno, da Cimabue in qua, Florencia, p. 232. Para su producción fuera de Roma, véase A. Ricci (1834), Memorie Storiche delle arti e degli artisti della Marca di Ancona, Macerata, I, p. 276. Baldinucci le llama Giovanni Carboni y le hace oriundo de Tolentino, quizá porque para el presbiterio de la iglesia de San Nicolás pintó dos telas, aunque es más probable que fuera natural de Sanseverino. Añade noticias nuevas A. Presenzini (1880), Vita ed opere del pittore Andrea Camassei, Asís, Tip. Sensi, p. 136-139.

64. L. LANZI (1795-1796), Storia pittorica dell'Italia, Remondini, Bassano del Grappa, I, p. 490.

65. E. Parlato (2007), «La processione di santa Rosa a Viterbo: Dall'iconografia quattrocentesca alle macchine barocche», en M. Fagiolo (a cargo de) (2007), Le capitali della festa: Italia centrale e meridionale, Roma, De Luca, p. 251-260.

66. B. Marinelli, «Ludovico Leonini», inédito, 2009, y «Gaetano Ze- 
nobi, stampatore e intagliatore tra Foligno e Roma (secc. XVII-XVIII)», inédito, 2014, accesibles en la web del Centro Studi Federico Frezzi (Foligno). En su testamento del año 1715, el pintor nombró heredero al sobrino librero, el cual renunció debido a las deudas del donante. Entre sus bienes aparece un libro di sbozzi di pitture. Por lo visto, hasta ahora nadie se ha hecho eco de la estancia romana del pintor.

67. No he sabido identificar a este artista. En el siglo Xvin son bien conocidos los hermanos Collino, escultores piamonteses.

68. J. Curzietti (2011), Giovan Battista Gaulli..., op. cit., n. 16.

69. C. Marchioni (1628-1709) fue desde el año 1667, junto con el yerno G. M. Hamerani, maestro di zecca. Desde el pontificado de Inocencio X aparece como medagliero segreto del papa, con taller all'insegna della Lupa situado en Via dei Coronari. Véase T. AymaMí (2014), «Aproximación al estudio de las medallas devocionales Hamerani de los siglos XVII-XVIII», Gaceta Numismática, 187, p. 15 39, con abundante bibliografía.

\section{J. Curzietti (2011), Giovan} Battista Gaulli..., op. cit., n. 14. El autor le describe como tejedor y mercader de damascos.

71. Junto con G. C. de Romanis, Banchieri bordó la indumentaria funeraria de Alejandro VIII. Véase A. Pampalone (2013), «"E la disposizione de'lavori, colla vaghezza del colorito, rendeano la vista, anchorché fúnebre, dilettevole": Il progetto di Mattia De Rossi per il catafalco di Alessandro VIII (1691)», Rivista d'Arte, 3, p. 299-316.

72. No consta su profesión, aunque era hijo de Mattia Bresi librator (nivelador o, más bien, artillero) de Castel Sant'Angelo. Es posible identificarle con el homónimo alférez de la tercera escuadra de artilleros de la misma fortaleza: Ruolo de'bombardieri di Castel Sant'Angelo di Roma, Roma, Francesco de Lazari, 1692, p. 11.

73. Nicolò Stamigna o Stamegna (Spello, 1615-Loreto, 1685), compositor y presbítero. Fue maestro de capilla de las catedrales de Spoleto (1635-1638), Perugia (1641-1643), Fabriano y Orvieto. En Roma lo fue de Santa María la Mayor (1659-1667) y Santiago de los Españoles (1667-1684). Participó en los funerales romanos de Felipe IV, como informa A. PÉrez De Rua (1666), Funeral becho en Roma en la Yglesia de Santiago de los Españoles a 18 de Diciembre de 1665 a la gloriosa memória del Rei Católico de las Españas Nuestro Señor D. Felipe Quarto el Grande, I, Roma, Dragondelli, p. 100.

\section{A. M. Listi (1671), Relatione} del sontuosissimo... (cfr. supra n. 37). La descripción de la fachada y los dos grabados fueron reproducidos por M. FAGIOLO DELL'ARCO (1997), La festa a Roma..., op. cit., I, p. 490-491. El narrador no es fray Giuseppe Paglia, como afirma este autor, sino Angelo Maria Listi, aunque es cierto que el dominico fue el diseñador y arquitecto de la fiesta.

75. P. Fr. Francesc Vidal Micó O. P. (1743), Historia de la prodigiosa vida, virtudes, milagros y profecías del Segundo Angel del Apocalypsi y Apóstol valenciano de las Indias Occidentales San Luis Bertrán..., Valencia, Joseph Thomás Lucas, p. 456.

76. Ibídem, p. 406-407. El pintor regaló el cuadro principal como exvoto. Los cuatro lienzos de los muros figuran milagros: la cruz inscrita en el árbol, la pistola convertida en crucifijo, la extinción del fuego en Albaida y la mujer convertida en las Indias. Los cinco cuadros son propiedad del $\mathrm{Mu}$ seo de Bellas Artes, aunque uno está depositado en la Conselleria
d'Hisenda de la Generalitat Valenciana (Milagro de la cruz inscrita en el árbol) y otro en el monasterio del Puig (El fuego de Albaida). Véase A. E. Pérez Sánchez (com.) (2001), Jerónimo Jacinto de Espinosa (1600-1667), catálogo de exposición, Museu de Belles Arts de Castelló, cat. 42-43. En 1736 se añadió un camarín a la capilla, con una pintura pagada por el $\mathrm{P}$. Vidal Micó figurando la Gloria de san Luis Bertrán, además de las esculturas de santa Magdalena y santa María Egipcíaca, esta última regalada por Lleonard Capuç. En la celda del santo había una pintura grande de Ribalta.

77. A. Alejos Morán (1983), «Presencia de San Luis Bertrán en la parroquia de San Esteban de Valencia», Cuadernos de San Luis Bertrán, 11, p. 516.

78. T. Echarte O. P. y A. MonTANer Frutos (2000), «Un grabado de San Luis Bertrán con las armas del marqués de Astorga», Emblemata, 6, p. 377-384. Se conserva un ejemplar policromado del grabado en el museo histórico de los dominicos de la provincia de Aragón, en el convento de Torrent (Valencia).

79. A. Negro (1999), La Collezione Rospigliosi: La quadreria e la committenza artistica di una famiglia patrizia a Roma nel Sei e Settecento, Roma, Argos (reed. Campisano, Roma, 2007), cat. 3. Los dos cuadros de Baldi aparecen en el inventario de 1713 con los números 693 i 708 (ibídem, p. 325-326).

80. La transcripción es literal, aunque para facilitar la lectura se desarrollan las abreviaturas, excepto las de comprensión más evidente. Las (pocas) pérdidas de texto se señalan con puntos suspensivos entre paréntesis. Se indican entre claudátores los añadidos al margen y las omisiones del notario de tipo formulario, que, a partir del primer recibo, se substituyen por un etcétera. 
